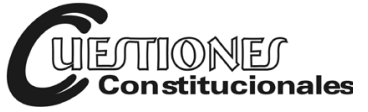 \\ Revista Mexicana de Derecho Constitucional \\ Núm. 26, enero-junio 2012
}

\section{EL PROCESO AL SERVICIO DE LOS DERECHOS ALCANCE DEL INTERÉS LEGÍTIMO EN EL DERECHO COMPARADO}

\author{
Francisco VÁZQUEZ GómEZ BISOGNO* \\ I. Planteamiento general: \\ el "neoconstitucionalismo procesal" \\ “...es necesario resaltar que los reque- \\ rimientos [del interés legítimo] están \\ enmarcados en un contexto constitu- \\ cional más amplio, que garantiza, entre \\ otros principios, la primacía del derecho \\ sustancial sobre el adjetivo, la eficacia \\ de los derechos fundamentales y la \\ informalidad de la acción de [amparo]...

Corte Constitucional de Colombia

Para nadie es desconocido el orgullo que sentimos los procesal-constitucionalistas mexicanos de ser naturales del país que le dio al mundo uno de los principales medios de control de la constitucionalidad, y es, por tal orgullo, que también debemos ser los primeros en no olvidar que dicha garantía fue concebida esencialmente para la defensa de los derechos de los más débiles.

* Titular de las cátedras de la Teoría Constitucional, Derecho Constitucional e Interpretación Constitucional de la Facultad de Derecho de la Universidad Panamericana.

1 T-961/09, Sala Segunda de Revisión de la Corte Constitucional, 18 de diciembre de 2009, María Victoria Calle Correa, consideración jurídica 3. 
Cuando en el Acta Constitutiva y de Reformas de 1847, primer documento constitucional mexicano que evocó al juicio de amparo, lo hizo, no refiriéndose exclusivamente a un procedimiento, sino más aún, se refería al amparo como una idea revolucionaria - misión constitucional a cargo de los jueces - consistente en que "los tribunales de la Federación [ampararían] a cualquiera habitante de la República, en el ejercicio y conservación de los derechos que le concedan esta Constitución y las leyes constitucionales, contra todo ataque de los poderes legislativo y ejecutivo, ya de la Federación, ya de los Estados....". ${ }^{2}$ No por nada, don Mariano Otero manifestaba en su famoso voto particular que si se "...ha observado que la amplitud y respetabilidad del Poder Judicial [es] el más seguro signo de la libertad de un pueblo (...) ésta garantía - el amparo - sólo puede encontrarse en el poder judicial, protector nato de los derechos de los particulares...". ${ }^{3}$

Así, el amparo era garantía en la medida en que fuera un verbo conjugado por los jueces y tribunales, evidenciando de esta manera que la pretensión de los juristas mexicanos del siglo XIX era privilegiar la protección de los derechos sobre el establecimiento de reglas adjetivas o procedimentales, lo que fácilmente se puede comprobar al analizar la primer sentencia de amparo, la cual, por su extensión, sencillez y claridad, así como por el hecho de que otorgara el amparo, aun cuando no existiera una ley que reglamentara el proceso, son muestras evidentes de que lo procesal debía quedar sometido a lo sustantivo. ${ }^{4}$ En suma, la decisión en ese entonces parecía contundente: el proceso debía estar al servicio de los derechos. Así considerado, el amparo era, en todo caso, un procedimiento elemental por la justicia.

\footnotetext{
2 Artículo 25 del Acta Constitutiva y de Reformas, del 21 de mayo 1847.

3 Voto particular de don Mariano Otero, 5 de abril de 1847.

4 La sentencia de amparo fue emitida el 13 de agosto de 1849 en San Luis Potosí por don Pedro Zámano (o Sámano), primer suplente del juzgado de Distrito en aquella ciudad, y en la cual señaló lo siguientes: “...teniendo presente que el artículo 25 de la Acta de Reformas, impone al juzgado a mi cargo la obligación de amparar a cualquier ciudadano contra los ataques violentos, ya sea de los supremos poderes de la nación, ya de los Estados: que la circunstancia de no haberse reglamentado el modo y términos en que tal protección [el proceso de amparo] debe dispensarse, no es ni puede ser un obstáculo para cumplir con ese sagrado deber...” Véase Arizpe Narro, Enrique, La primera sentencia de Amparo, México, SCJN, 2006, pp. 45 y 46.
} 
No por nada, en su propuesta de reformas a la Constitución mexicana de 1857, Venustiano Carranza afirmaba ante el Congreso Constituyente en la sesión del 1o. de diciembre de 1916 que:

Siendo el objeto de todo Gobierno el amparo y protección del individuo, o sea de las diversas unidades de que se compone el agregado social, es incuestionable que el primer requisito que debe llenar la Constitución Política, tiene que ser la protección otorgada, con cuanta precisión y claridad sea dable, a la libertad humana, en todas las manifestaciones que de ella derivan de una manera directa y necesaria, como constitutivas de la personalidad del hombre (...) Partiendo de este concepto, que es el primordial, como es el que tiene que figurar en primer término, marcando el fin y objeto de la institución de Gobierno, se dará a las institucionessociales su verdadero valor...5

En torno a estas afirmaciones, bien podríamos preguntarnos:

¿puede decirse que para Carranza la Constitución debía ordenarse a partir de los derechos de la persona?, [a lo que Cossío contesta] A mi juicio sí, si atendemos a lo dicho en la parte final de su propio Informe, donde señalaba que las reformas [tenderían] a asegurar las libertades públicas por medio del imperio de la ley, a garantizar los derechos de todos los mexicanos por el funcionamiento de una justicia administrada por hombres probos y aptos...6

Sin embargo, es evidente que el devenir del amparo mexicano provocó que a finales del siglo XX se le considerara — más bien- un proceso alejado de su concepción más genuina. Iniciada la segunda década del siglo XXI, nadie en su sano juicio podía negar que el amparo mexicano, si bien había sido punta de lanza en el siglo XIX en materia de garantías constitucionales, también era cierto que se había convertido en una institución torpe, lenta y tortuosa, producto esto en gran medida de la visión iuspositiva y formalista del derecho, visión la

5 Diario de los Debates del Congreso Constituyente, Querétaro, 1o. de diciembre de 1916, núm. 12, t. I, p. 262, http://www.diputados.gob.mx/LeyesBiblio/ref/cpeum/ Proy_CPEUM_expmot_01dic1916.pdf.

${ }_{6}$ Cossío Díaz, José Ramón, "Ordenación y jerarquización constitucionales", en Carbonell, Miguel (comp.), Teoría constitucional y derechos fundamentales, México, CNDH, 2002, p. 92. 
cual había marcado su proceso "evolutivo" —o como dirían muchossu proceso involutivo. Hoy es esperanzador que tal involución parece haber concluido.

Diversas y muy variadas habían sido las llamadas de atención que - con un ánimo modernizador - se habían emitido para transformar al amparo en sus principios fundamentales a través de diversos proyectos o iniciativas de enmiendas a la Constitución mexicana; enmiendas que quizá eran ínfimas en cuanto a su extensión pero que resultarían magnánimas en cuanto a sus efectos.

Por mencionar sólo una de las llamadas que - hacia la modernidad sustantiva y procesal- habían permanecido estériles a lo largo de los últimos diez años, nombraremos la propuesta de "nueva" Ley de Amparo que realizara la Comisión Especial creada por la Suprema Corte de Justicia de la Nación en 1999, y que rindiera sus primeros frutos en el 2001, con la presentación ante la opinión pública y el foro jurídico de un proyecto integral e innovador de reformas constitucionales y legales en materia de amparo. Sin embargo, a pesar del ímpetu transformador generado a lo largo de los dos o tres años posteriores a su presentación, tiempo después no nos quedaba más que referirnos a dicho proyecto como "nuevo" —así, entre comillas—, ya que de nuevo ya no tenía nada.

No obstante, y derivado de que diversos senadores presentaran una iniciativa de reforma constitucional a inicios de 2009, la cual, al retomar el noventa y cinco por ciento de las propuestas de la Suprema Corte, aquél proyecto adquirió nuevamente una relevancia indiscutible, lo que posibilitó rescatarlo de los gélidos "congeladores" parlamentarios del Congreso de la Unión. Roto así el estatus quo que se había producido en torno a la modernización del amparo, la reforma constitucional publicada el 6 de junio de 2011 en el Diario Oficial de la Federación constituye, sin duda, el primer paso en la revitalización del juicio de protección de los derechos humanos del sistema jurídico mexicano.

Así, dado este primer paso, y tomando en consideración que la Constitución mexicana, para abril de 2011, había sufrido "tan sólo" 503 enmiendas, no exagero si parafraseando al astronauta Armstrong, afirmo de forma similar a cómo él lo hizo en 1969 respecto de la llegada del hombre a la luna, que esta reforma constitucional es un pequeño paso para un texto constitucional, pero un gran salto para el amparo mexicano y para el sistema de control constitucional en México. 
Ya en una entrega anterior, y so pretexto de la conmemoración de los 160 años de la primera sentencia de amparo, realicé algunas reflexiones para identificar, de entre todas las propuestas que se comentaban y analizaban en esos momentos (2009), cuáles eran — a mi parecer- los cuatro derroteros mínimos que debían indefectiblemente transitarse para revitalizar al amparo mexicano. ${ }^{7}$ En aquel entonces la reforma constitucional que hoy es una realidad, sólo había sido aprobada por el Senado de la República, lo que me permitía — en esos momentos - emitir algunas consideraciones con el objeto de perfeccionar aún más tal dictamen que transitaba en calidad de minuta hacia la Cámara de Diputados para sus efectos constitucionales. Como sea, tal minuta sería aprobada prácticamente en los mismos términos por la Cámara de Diputados (2010), ocurriendo lo mismo en las legislaturas de los estados (2011).

En aquel entonces consideré que una reforma al amparo sería de fondo si, y sólo si, se transitaba (i) de las garantías individuales al derecho internacional de los derechos humanos; (ii) de la jurisprudencia nacional a los criterios de los organismos internacionales; (iii) de la protección individual a la protección con efectos generales, y (iv) del interés jurídico al interés legítimo. De los cuatro movimientos señalados, tres forman parte hoy de la reforma constitucional (i, iii y iv), y sólo uno (el ii) deberá ser un movimiento que se geste vía interpretación judicial. ${ }^{8}$ Por lo anterior, soy enfático en afirmar que la reforma constitucional en materia de amparo - junto con la de derechos humanos - ${ }^{9}$ deban ser consideradas las enmiendas constitucionales más importantes en la historia de la Constitución mexicana de 1917.

7 Ferrer Mac-Gregor, Eduardo y González Oropeza, Manuel (coords.), El juicio de amparo. A 160 años de la primera sentencia, México, UNAM, 2011.

8 De poco sirve la protección de los derechos humanos de los tratados internacionales si no se atiende a la forma en que los organismos internacionales los han aplicado en la resolución de los casos sometidos a su conocimiento. Este es el verdadero cambio que nos acercará aún más a lo que Pereira Menaut ha considerado que configura el Rule of Law (Imperio del derecho), es decir, la existencia de alguna entidad jurídica de la cual los poderes constituidos, y el propio Estado, carezcan de jurisdicción. En suma, para la real y efectiva vivencia de un imperio del derecho debe reconocerse alguna entidad jurídica superior, anterior y/o exterior al propio Estado, lo cual se actualizaría con el reconocimiento de la jurisprudencia internacional como fuente formal del derecho mexicano. Véase Pereira Menaut, Carlos-Antonio, Lecciones de teoría constitucional, México, Porrúa-Universidad Panamericana, 2005, p. 86.

9 Publicada en el Diario Oficial de la Federación el 10 de junio de 2011. 
No obstante, y sin ánimos de ser un aguafiestas, hay otros dos pasos de los que dependerá si tal reforma constitucional puede o no llegar a feliz puerto.

Me refiero, en primer lugar, a los cambios que deberán realizarse a la legislación secundaria a fin de terminar por recorrer por completo los derroteros marcados por la reforma constitucional. Deberá emitirse una nueva Ley de Amparo que detalle e instrumentalice, entre otras cosas: los plenos de Circuito y la nueva forma de emisión de la jurisprudencia; la facultad del Ejecutivo y Legislativo para solicitar la atención prioritaria de asuntos; la forma en que serán protegidos los derechos vía amparo; la declaratoria general de inconstitucionalidad; el nuevo amparo directo y la inclusión del amparo adhesivo; las modificaciones al régimen suspensional y la inclusión del concepto de la "apariencia del buen derecho", las modificaciones al régimen de incumplimiento de las sentencias de amparo, y claro está, el interés legítimo.

Lo que es más, deberán reformarse un sinnúmero de leyes federales y locales a fin de armonizar toda la regulación secundaria a los nuevos bríos constitucionales. Por mencionar sólo un ejemplo, y tomando en consideración la ya mencionada reforma constitucional en materia de derechos humanos, esos bríos constitucionales a los que me he referido consisten en que nuestra ley fundamental abandonó el concepto de "garantías individuales" y lo sustituyó, como debe ser, por el concepto de "derechos humanos". Dado este cambio, confío en que por primera vez - desde que un servidor tiene uso de memoria - el legislador secundario abandone la nefasta práctica legislativa de la inclusión de una "clausula general de derogación" 10 que establezca que la sustitución de tales conceptos debe realizarse por arte de magia.

10 Miguel Carbonell señalará que “...la cláusula general de derogación, además de ser inútil (...) es sumamente perniciosa por varias razones, entre las que se pueden mencionar las siguientes: a) porque no aclara cuáles son exactamente las normas que quedan derogadas, b) como consecuencia de lo anterior los destinatarios de las leyes y los operadores jurídicos no saben con certeza el derecho aplicable a los diversos casos concretos, y c) la derogación hecha de esta forma debe ser determinada a través de la interpretación conjunta de la nueva norma y de la norma presuntamente derogada; esa interpretación la llevan a cabo los jueces — no únicamente ellos, pero sí que son los únicos que lo hacen de forma obligatoria-, de lo que resulta una disminución del papel del Poder Legislativo en la función de configuración del ordenamiento vigente, con todo lo que ello implica dentro de un ordenamiento democrático. Lo correcto es que el legislador elabore unas tablas de derogación en donde se señalen, todo lo exhaustivamente 
Confío en que el legislador secundario sabrá entender el cambio sustantivo que implicó el abandono de una "sacrosanta" decisión política fundamental del Constituyente queretano de 1917, y reconozca la importancia, no sólo jurídica, sino sobre todo antropológica, filosófica y política que implica el mudar del iuspositivista "otorgamiento de garantías" al iusnaturalista "reconocimiento de los derechos". Como lo referí, este es sólo un ejemplo en el que espero que el legislador no repare en terminar de "impregnar" toda la legislación secundaria con el nuevo ánimo del Constituyente Permanente. ${ }^{11}$ De esta forma, las reformas a las leyes secundarias serán sólo el segundo paso en la materialización de la enmienda constitucional.

Llegado a este punto, resulta necesario hablar del tercer paso. No creo exagerar al afirmar que serán los jueces - $\mathrm{y}$ la función interpreta-

que se pueda, las normas que quedan derogadas". Véase Carbonell, Miguel, "Los objetos de las leyes, los reenvíos legislativos y las derogaciones tácitas", en Carbonell, Miguel y Pedroza de la Llave, Susana Thalía (coords.), Elementos de técnica legislativa, México, UNAM, 2000, p. 220, http://www.bibliojuridica.org/libros/1/21/tc.pdf.

11 Cabe señalar que no es un trabajo muy complicado, al punto de que por lo que hace a la legislación secundaria federal, el tránsito del concepto de las "garantías individuales» al concepto de «derechos humanos» implicaría el ajuste a las siguientes leyes: Código de Comercio (artículo 1074), Código de Justicia Militar (artículo 80, 86, 769), Código Federal de Instituciones y Procedimientos Electorales (artículos 38, 103, 230), Código Federal de Procedimientos Civiles (artículo 555), Código Federal de Procedimientos Penales (artículo 154, 193), Estatuto de Gobierno del Distrito Federal (artículo 16), Ley de la Comisión Nacional de los Derechos Humanos (artículos 31 y 44), Ley de Cámaras Empresariales y sus Confederaciones (artículo 37), Ley de Fomento para la Lectura y el Libro (artículo 3o.), Ley de la Policía Federal (artículo $3^{\circ}, 5^{\circ}, 1^{\circ}$, 49), Ley de Planeación (artículo 2o.), Ley de Premios, Estímulos y Recompensas Civiles (artículo 109, 112), Ley de Responsabilidad Civil por Daños Nucleares (artículo 26), Ley de Seguridad Nacional (artículos 4o., 25, 31, 61), Ley Federal de Defensoría Pública (artículo 6o.), Ley Federal de Procedimiento Administrativo (artículo 61), Ley Federal de Responsabilidades de los Servidores Públicos (artículo 7o.), Ley Federal para Prevenir y Eliminar la Discriminación (artículo 14), Ley Federal para Prevenir y Sancionar la Tortura (artículo 2o.), Ley General de Cultura Física y Deporte (artículo 118), Ley del Sistema Nacional de Seguridad Pública (artículo 25, 40), Ley Orgánica de la Administración Pública (artículo 27), Ley Orgánica de la Procuraduría General de la República (artículo 5o.), Ley Sobre la Aprobación de Tratados en Materia Económica (artículo 2o.), Ley para la Protección de los Derechos de Niñas, Niños y Adolecentes (artículos 1o., 4o.), Ley de Transparencia y Acceso a la Información Pública Gubernamental (artículo 14), Ley General de Acceso a las Mujeres a una Vida sin Violencia (artículo 16), Ley General de Población (artículo 3o.), Ley de Tratamiento de Menores Infractores (artículo 56). 
tiva que desarrollan - la que será determinante como tercer paso en la cristalización de la reforma constitucional, ya que no debemos olvidar que, nos guste o no, “...todos estamos bajo la Constitución, pero los jueces [constitucionales] dicen qué es la Constitución...". ${ }^{12}$ Así, las reformas legales y la interpretación judicial, serán el segundo y tercer paso que deberán encaminarse hacia la concreción de la decisión axiológica fundamental que, a mi parecer, ha tomado el Órgano reformador de la Constitución, rescatando las ideas del Constituyente de1847, y que se deriva no sólo de la aprobación de la reforma constitucional en materia de amparo, sino sobre todo, de la relación que ésta última tiene con la reforma constitucional en materia de derechos humanos, así como con la reforma que constitucionalizó las acciones colectivas: ${ }^{13} \mathrm{el}$ "neoconstitucionalismo procesal" implica que el proceso debe estar al servicio de los derechos.

Para entenderlo con claridad, es imprescindible comentar que el concepto de "neoconstitucionalismo procesal" ha sido desarrollado por la jurisdicción constitucional venezolana a partir del principio de "fin útil de la nulidad”, según el cual: “...no puede pronunciarse la nulidad por inobservancia de formas de ningún acto del proceso [salvo que] el acto carezca de los requisitos formales indispensables para alcanzar su finalidad. La nulidad en definitiva, no puede pronunciársela nunca si el acto ha alcanzado la finalidad a que está destinado...", o dicho de otra forma, que “...los órganos jurisdiccionales están constitucionalmente obligados a interpretar las normas con los requisitos procesales y respetando a su vez las garantías jurisdiccionales, teniendo siempre presente el fin perseguido por el legislador al establecerlos, evitando

12 Charles Evans Hughes, antes de ser el decimoprimer chief justice de la Corte Suprema norteamericana, señalaba textualmente en 1907 (siendo gobernador de Nueva York): "We live under a Constitution; but the Constitution is what the judges say it is". Véase Hughes, Charles Evans, La Suprema Corte de los Estados Unidos, México, Fondo de Cultura Económica, 1971 y Landa, César, "Teorías de la interpretación judicial”, en Ferrer Mac-Gregor, Eduardo (coord.), Derecho procesal constitucional, 5a. ed., México, Porrúa, 2006, t. IV, p. 3483.

13 Reforma publicada el 29 de julio de 2010 en el Diario Oficial de la Federación, la cual, adicionó al artículo 17 constitucional (derecho de acceso a la justicia) el siguiente párrafo: "El Congresode la Unión expedirá las leyes que regulen las acciones colectivas. Tales leyes determinarán las materias de aplicación, los procedimientos judiciales y los mecanismos de reparación del daño. Los juecesfederales conocerán de forma exclusiva sobre estos procedimientos y mecanismos". 
cualquier exceso formalista que convierta a tales artículos en mero obstáculos procesales impeditivos de la Tutela Judicial efectiva...". ${ }^{14}$

Así, serán los legisladores secundarios y los jueces constitucionales los que terminen por resolver un desiderátum que suele plantearse ante reformas del calado de las comentadas: ¿el cambio radicará en la generación y adopción de una nueva visión jurídica, o simplemente en la adaptación de lo "nuevo" a la visión pretérita del derecho?

Considero que de la forma en que los órganos legislativos y judiciales respondan a esta interrogante, dependerá el éxito de la reformas y de la concreción o no del ya mencionado "neoconstitucionalismo procesal".

De esta personal forma de mirar la realidad, es que he considerado importante analizar - muy concretamente - uno de los cambios que en el ayer advertí como uno de los derroteros que debían transitarse para revitalizar al amparo mexicano. Me refiero al tránsito del interés jurídico al interés legítimo.

La parte de la reforma objeto de nuestro análisis resulta simple en su formulación, ya que no hace otra cosa más que matizar el principio de instancia de parte agraviada, lo cual, dicho sea de paso, no requería de una reforma constitucional, sino en todo caso, una reforma a la fracción V del artículo 73 de la Ley de Amparo vigente, a fin de que eliminar la causa de improcedencia consistente en que el juicio no podrá interponerse en contra de actos que no afecten los intereses jurídicos de los demandantes. Sin embargo, es aquí dónde observo como el órgano reformador de la Constitución quiso dar un mensaje claro al legislador y al juez, ubicando desde el texto de nuestra ley fundamental, la forma en que ahora debe interpretarse el ya referido principio de instancia de parte agraviada. Lo hizo de la siguiente manera:

Artículo 107. Las controversias de que habla el artículo 103 de esta Constitución, con excepción de aquellas en materia electoral, se sujetarán a los procedimientos que determine la ley reglamentaria, de acuerdo con las bases siguientes:

14 Sentencia sobre el expediente 6.132-07, acción de amparo constitucional, 13 de febrero de 2007 y sentencia sobre el expediente 6.105-06, nulidad de matrimonio, 14 de febrero de 2007, ambas del Juzgado Superior en lo Civil, Mercantil, Bancario, del Tránsito y de Protección del Niño y del Adolescente de la Circunscripción Judicial del Estado Guarico, Tribunal Supremo de Justicia de Venezuela, http:/guarico.tsj.gov.ve/. 
I. El juicio de amparo se seguirá siempre a instancia de parte agraviada, teniendo tal carácter quien aduce ser titular de un derecho o de un interés legítimo individual o colectivo, siempre que alegue que el acto reclamado viola los derechos reconocidos por esta Constitución y con ello se afecte su esfera jurídica, ya sea de manera directa o en virtud de su especial situación frente al orden jurídico.

Tratándose de actos o resoluciones provenientes de tribunales judiciales, administrativos o del trabajo, el quejoso deberá aducir ser titular de un derecho subjetivo que se afecte de manera personal y directa;

En más de una ocasión - para ser honestos, en muy diversas ocasiones - he escuchado que uno de los cambios más significativos de la reforma lo constituye la adopción del interés legítimo. Todos hablan del interés legítimo, y cómo no hacerlo si está de moda. El problema viene cuando dichas apreciaciones son, por lo regular, comentarios abstractos, dogmáticos y hasta sacramentales, cuando por ejemplo, se apela a tal o cual autor para definir la figura. Por el contrario, nunca he escuchado a algún comentarista hablar de una forma concreta, práctica o tópica que me permita advertir, sin discursos pomposos y sin la elucubración de grandes teorías jurídicas, cuál es el impacto específico de una institución como el interés legítimo en el sistema de justicia constitucional.

No pasa desapercibido para el que esto escribe que en el ordenamiento jurídico mexicano existen un sinnúmero de normas - en todos los niveles de gobierno- que reconocen el interés legítimo para la realización de trámites, presentación de solicitudes e instauración de procedimientos; incluso, no se desconoce que el mismo Poder Judicial de la Federación ha abordado el concepto, por ejemplo, so pretexto de la aplicación de leyes fiscales o administrativas, o bien, en materia de controversias constitucionales. No obstante, y respecto de la tutela de los derechos fundamentales reconocidos en el sistema jurídico mexicano, así como de las garantías constitucionales para su protección, es evidente que la línea jurisprudencial es una: el interés legítimo no abre las puertas del proceso constitucional de protección para los derechos humanos.

Y para muestra un botón. La última tesis de jurisprudencia que, en junio de 2011 aparece publicada en el Semanario Judicial de la Federación relativa al tema objeto de análisis, señala lo siguiente: 
INTERÉS JURÍDICO. CARECE DE ÉL UNA ASOCIACIÓN DE VECINOS PARA LA DEFENSA DE DERECHOS AMBIENTALES COMO TERCERA EXTRAÑA A UN JUICIO INTERDICTAL.

De acuerdo con la doctrina y la jurisprudencia el interés jurídico presupone la existencia de un derecho subjetivo protegido por la ley, que es violado o desconocido, con lo cual se infiere un perjuicio a su titular, facultándolo para acudir ante los órganos jurisdiccionales a demandar que esa transgresión cese; en tanto que el interés legítimo es una situación jurídica activa por relación a la actuación de un tercero y sin implicar, a diferencia del derecho subjetivo, una obligación correlativa de dar, hacer o no hacer exigible de otra persona, pero sí la facultad del interesado de exigir ante la administración pública el respeto al ordenamiento jurídico y, en su caso, una reparación de los perjuicios que de esa actuación deriven. En ese contexto, una agrupación vecinal legalmente constituida carece de interés jurídico al pretender sea oída en el proceso de origen, apoyándose en que el inmueble controvertido se encuentra en una zona protegida por las normas locales y que la demolición de la obra cuestionada causará un menoscabo al derecho que tienen sus integrantes a vivir en un ambiente adecuado para su desarrollo y bienestar, dado que únicamente la legitima a defenderlos ante las autoridades administrativas, confirmándose este punto de vista con las modificaciones que se pretenden a la Ley de Amparo, entre otras, la referente a que el interés legítimo resulte bastante para ejercitar la acción constitucional, exceptuándose los supuestos en que los actos provengan de un expediente sustanciado ante los jueces o tribunales. ${ }^{15}$

Como puede observarse, es el propio tribunal colegiado de circuito quien reconoce que no existe la posibilidad de ejercitar la acción constitucional de amparo mediante un interés legítimo debido a que, dicho sea de paso, existe la pretensión de modificar para tales efectos la Ley de Amparo, lo cual es esos momentos no había ocurrido.

Por ello, como lo he afirmado líneas arriba, la reforma constitucional de amparo debe ser considerada una de las enmiendas constitucionales más importantes en la historia de la Constitución mexicana de 1917 , sin embargo, la magnificencia de sus efectos no dependerá de su letra o de las grandes teorías que podamos construir a partir de la misma. En lo personal, tal magnificencia dependerá — sobre todo- de la forma en

15 Tesis: III.5o.C.31 K, Semanario Judicial de la Federación y su Gaceta, Novena Época, t. XXXI, junio de 2010, p. 931, registro 164464. 
cómo nuestros jueces configuren una doctrina jurisprudencial del interés legítimo a partir de la apertura o cierre con que permitan o no la entrada de nuevos y paradigmáticos casos que, muy seguramente, comenzarán a presentarse en nuestro país, lo cual, dicho sea de paso, dependerá también de la inventiva e imaginación con la que los litigantes construyan los argumentos de sus demandas de amparo.

Es por todo lo anterior, que lo pretendido a lo largo de estas líneas sea dar una visión clara, concreta, objetiva, pero sobre todo práctica, de lo que es el interés legitimo y del alcance que ha tenido esta institución jurídica en otras latitudes, a fin de que los procesal-constitucionalistas mexicanos reflexionemos sobre la forma en que debemos entender e instrumentar dicha institución en nuestra realidad. Los principios y bases ya son letra constitucional, ahora dependerá de nosotros lo que hagamos con ellas, para lo cual habrá que decidir, en todo caso, si apostamos o no por un "neoconstitucionalismo procesal".

II. El interés legítimo en el derecho comparado: alcance, contenido y configuración jurisprudencial

“...la comparación jurídica es uno de los métodos a los cuales recurren los tribunales constitucionales en la interpretación (...) junto a los métodos literal, sistemático, histórico y teleológico, que tienen su origen en la clásica formulación de Savigny, Häberle ha colocado al comparativo como quinto método de interpretación, como estadio imprescindible en la exégesis de las cláusulas constitucionales...". ${ }^{16}$ Giuseppe de Vergottini

\section{Finalidad e importancia práctica del derecho comparado}

Tal y como lo refiere Giuseppe de Vergottini, para nadie es desconocido que realizar estudios o análisis de derecho comparado sea cada

16 Vergottini, Giuseppe de, Derecho constitucional comparado, trad. de Claudia Herrera, México, UNAM, Instituto de Investigaciones Jurídicas, 2004, p. 12, http:// www.bibliojuridica.org/libros/libro.htm?l=1476. 
vez más recurrente por parte de los operadores jurídicos a fin de otorgar mayor solidez a sus conclusiones, investigaciones, interpretaciones o edificaciones argumentativas. Sobre este particular, resulta importante advertir que:

...el recurso por parte de los magistrados a experiencias extranjeras en el proceso de fundamento judicial puede ser fácilmente identificado en los más diferentes momentos históricos de toda la tradición constitucional occidental. Es recurrente, por lo tanto, la referencia a la doctrina extranje$\mathrm{ra}$, a la legislación comparada $\mathrm{y}$, recientemente con especial énfasis, a los precedentes judiciales de tribunales extranjeros y de instancias supranacionales. ${ }^{17}$

Así, el "argumento comparativo" se hace consistir “...por citas de otros sistemas jurídicos con la pretensión de generar universalidad o diferenciación, y se fundan en la consideración de un estado de cosas jurídico de una sociedad distinta...", ${ }^{18}$ intentando “...traer una solución jurídica establecida en el mismo o respaldar la que se propone...". ${ }^{19}$ De esta manera, no es difícil comulgar con tal método de la argumentación, máxime si el concepto de sistema jurídico "...debe ser planteado de manera modesta en el sentido de que sólo será posible un sistema "débil", "poroso" o "abierto" en tanto necesariamente no impedirá que ingrese al mismo directamente material jurídico proveniente desde afuera del mismo....". ${ }^{20}$

17 Pinto Bastos Junior, Luiz Magno, "Utilización del derecho constitucional comparado en la interpretación constitucional: nuevos retos a la teoría constitucional", Estudios Constitucionales, Chile, año 5, núm. 2, 2007, p. 252, http://redalyc.uaemex.mx/ pdf/820/82050212.pdf.

18 Huerta, Carla, "Interpretación constitucional”, en Ferrer Mac-Gregor, Eduardo y Zaldivar Lelo de

Larrea, Arturo (coords.), La ciencia del derecho procesal constitucional. Estudios en homenaje a Héctor Fix-Zamudio en sus cincuenta años como investigador del derecho, México, UNAM, Instituto de Investigaciones Jurídicas, 2008, t. VI, p. 309, http://www. bibliojuridica.org/libros/6/2560/16.pdf.

19 Vigo, Rodolfo Luis, "La argumentación constitucional”, en Báez Silva, Carlos, Cienfuegos Salgado, David y Vázquez-Mellado García, Julio César (coords.), Interpretación, argumentación y trabajojudicial, México, Porrúa-Facultad de Derecho UNAMUniversidad Panamericana, 2009, p. 238.

20 Vigo, Rodolfo Luis, "Constitucionalización y neoconstitucionalismo: riesgos y prevenciones”, op. cit., p. 439. 
Ahora bien, atendiendo al análisis de profesor Pinto Bastos, debemos advertir que la utilización del "argumento comparativo" tiene diversas finalidades, a saber: (i) como forma de suplir lagunas en el sistema provenientes del deber de non liquet del Poder judicial; (ii) como forma de sanar obscuridades del texto y subsidiar decisiones en casos nuevos y desafiadores; (iii) como forma de legitimar la actuación de instituciones recién creadas u órdenes democráticas (re)instauradas mediante el préstamo de la autoridad provenientes de instituciones y experiencias constitucionales ya consolidadas; (iv) como forma de aumentar el grado de legitimidad internacional de actuación de la corte; (v) o, incluso, como mero ornamento constitucional por la erudición de los magistrados. ${ }^{21}$

De esta manera, es claro que la intensión de apelar al derecho comparado en el tema que se analiza, responde concretamente a la tercera de las finalidades mencionadas, es decir, legitimar la actuación de instituciones recién creadas u órdenes democráticas (re)instauradas mediante el préstamo de la autoridad provenientes de instituciones y experiencias constitucionales ya consolidadas. Así, si lo que pretendemos es responder a la pregunta de cuál será el impacto del interés legítimo en relación con el planteamiento de más y nuevas demandas de amparo, no nos queda más que atender a la forma en cómo dicha figura se ha aplicado en otros sistemas jurídicos, y de esta manera advertir, qué tipo de nuevos casos comenzaremos a ver dentro del sistema de justicia constitucional mexicano.

Dicho lo anterior, y a sabiendas de que concentraremos nuestros esfuerzos en los sistemas jurídicos español y colombiano, pasemos pues a su análisis.

\section{El interés legítimo y Tribunal Constitucional español.}

Sin temor a equivocarnos, uno de los países con mayor tradición e impulso de la figura, no sólo de interés legítimo, sino también de la figura del interés simple o difuso, es el constitucionalismo español. Por lo que hace a la figura del interés legítimo, la Constitución Española (CE) de 1978 establece en sus artículos 24.1 y 162.1 b), lo siguiente:

21 Pinto Bastos Junior, Luiz Magno, op. cit., 252. 
Artículo 24.1. Todas las personas tienen derecho a obtener tutela efectiva de los jueces y tribunales en el ejercicio de sus derechos e intereses legítimos, sin que, en ningún caso, pueda producirse indefensión.

Artículo 162.1. Están legitimados: b) Para interponer el recurso de amparo, toda persona natural o jurídica que invoque un interés legítimo, así como el Defensor del Pueblo y el Ministerio Fiscal.

Ahora bien, por lo que hace a la figura del interés simple, y debido a que no es el objeto de la presente investigación, me limitaré a mencionar que España es uno de los principales precursores de tal figura, ya que su Constitución reconoce en el artículo 125 que “...los ciudadanos podrán ejercer la acción popular...", lo que posteriormente encuentra oportuno desarrollo — por ejemplo- en la Ley de Enjuiciamiento Criminal, norma que establece en su artículo 101 lo siguiente: "La acción penal es pública..." y en su artículo 270 que: "Todos los ciudadanos españoles, hayan sido o no ofendidos por el delito, pueden querellarse...".

Pero a lo que deseo referirme es a la forma en que el Tribunal Constitucional español ha aplicado el interés legitimo. Sobre la interpretación que el este Tribunal ha dado a esta figura puede decirse que su criterio general de interpretación ha sido amplio en relación con los requisitos procesales y, más en concreto, de las normas que regulan la legitimación. Así, ha señalado que el “....interés legítimo, real y actual, (...) puede ser tanto individual como corporativo o colectivo y (...) también puede ser directo o indirecto, en correspondencia con la mayor amplitud con la que se concibe en el texto constitucional la tutela judicial de la posición del administrado y la correlativa necesidad de fiscalizar el cumplimiento de la legalidad por parte de la administración". ${ }^{22}$

Así, la magistratura constitucional española ha optado, por regla general, en darle al interés legítimo la mayor amplitud posible a efecto de concretar la obligación constitucional consistente en que no pueda producirse indefensión en caso alguno (artículo 24.1 de la Constitución Española). No obstante, si bien ha partido de una concepción amplia del interés legítimo, lo cierto es que en su aplicación práctica ha determinado que existen otros condicionantes que lo han llevado a adoptar posiciones un poco más restrictivas. Este último tipo de resoluciones lo que nos deja ver es que, aun partiendo de la premisa de que esta figura

${ }^{22}$ STC 195/1992, fundamento jurídico 4. 
generará un sistema de justicia de puertas abiertas, serán los tribunales los que - en definitiva - terminen por decidir qué tanto quedarán abiertas las puertas del proceso constitucional.

Lo anterior guarda cierta lógica si se toma en consideración que:

...la legitimación no depende sólo del interés que en abstracto pueda tener una persona física o jurídica (...) sino también del tipo de proceso de que se trate, y el recurso de amparo es en España [como en México] un proceso especial, configurado como una vía de tutela dedeterminados derechos fundamentales frente a actuaciones del poder público, [por lo que no es] una vía para la garantía de intereses difusos o para el control abstracto de la constitucionalidad de disposiciones normativas, y esto va a condicionar el alcance de la legitimación. ${ }^{23}$

De ahí que el Tribunal Constitucional español haya insistido, desde la década de los ochenta en que el interés legítimo no debe confundirse con el interés jurídico o directo, el cual resulta ser restrictivo de la titularidad personal del derecho fundamental, ${ }^{24} \mathrm{y}$ que tampoco debe entenderse en términos tan amplios que sea posible identificarlo con el interés simple o difuso propio de la acción pública o la acción popular en defensa de la ley. ${ }^{25}$ De ahí que se afirme por parte de los juristas españoles que “...en los supuestos en los que el Tribunal Constitucional se ha pronunciado expresamente sobre la concurrencia o no del interés legítimo (...) no siempre - y muy probablemente ni siquiera en la mayoría de los casos - ha advertido la legitimación". ${ }^{26}$

Así, de manera doctrinal podemos ubicar tres grandes tipos de interés en cuanto a la legitimación que se tiene para ejercitar la acción ante un órgano jurisdiccional: (i) interés jurídico o directo: cuya característica es ser restrictivo para acceder a la justicia toda vez que supone la afectación personal y directa a un derecho del cual el demandante debe ser el titular, ${ }^{27}$ (ii) interés legítimo: cuya característica es ser más permisi-

23 Gómez Montoro, Ángel J., "El interés legítimo para recurrir en amparo. La experiencia del Tribunal Constitucional Español”, Cuestiones Constitucionales, México, núm. 9, julio-diciembre de 2003, p. 164.

24 STC 47/1990, fundamento jurídico 2.

25 ATC 399/1982.

26 Gómez Montoro, Ángel J., op. cit., p. 170.

27 Por ejemplo, ante la orden de demolición de un pórtico del siglo XIX, sólo el propietario del mismo podría ejercitar alguna acción ante la jurisdicción. 
vo para acceder a la justicia toda vez que supone que el demandante guarda una especial situación frente al orden jurídico, ${ }^{28}$ y (iii) interés simple o difuso: cuya característica es ser absolutamente permisivo para acceder a la justicia toda vez que supone que el demandante debe y puede cuidar la constitucionalidad de cualquier acto. ${ }^{29}$

No cabe la menor duda que tomar en consideración estos tres últimos puntos, será fundamental para la construcción de una doctrina jurisprudencial que sobre el interés legítimo deberá desarrollar la magistratura constitucional mexicana.

Con base en esta concepción, el Tribunal Constitucional español ha dado entrada, entre otros casos, a los siguientes, lo cuales se mencionan por considerarse ejemplificativos para cumplir los objetivos del presente estudio: advertir qué tipo de nuevos casos comenzaremos a ver planteados ahora dentro del sistema de justicia constitucional mexicano. Veamos:

\section{A. Padres de Fermina González vs. Televisión Española} STC 190/1996 (25 de noviembre de 1996)

En este interesante precedente, el Tribunal Constitucional español reconoció el interés legítimo de los familiares de una persona fallecida para alegar violaciones a los derechos al honor, a la intimidad y a la propia imagen del de cujus.

A raíz del fallecimiento de Fermina González, se publicó una noticia por parte de la Televisión Española en la que se manifestó que:

...las últimas investigaciones descartan el asesinato y „se centran en el consumo de droga" [ya que el] cuerpo de Fermina González no tenía navajazos ni había sido violada, como se decía en un principio. Ayer más de 5.000 vecinos de Sant Celoni se manifestaron solicitando la aclaración del caso. Hoy el "Diario de Barcelona" dice que la pista

28 Por ejemplo, ante la orden de demolición de un pórtico del siglo XIX, no sólo el propietario del mismo podría ejercitar alguna acción ante la jurisdicción, sino también un vecino de la comunidad en que dicha construcción se encuentre.

29 Por ejemplo, ante la orden de demolición de un pórtico del siglo XIX, no sólo el propietario o el vecino podrían ejercitar alguna acción ante la jurisdicción, sino cualquier ciudadano que considere que tal demolición podría afectar un interés urbanístico o estético de esa comunidad. 
que siguen las investigaciones tiene que ver con la eventual relación de Fermina González con la droga. El Ayuntamiento ha confirmado que el análisis del cadáver indica que puede ser que la joven consumiese stimulantes desde hacía tiempo, y que se encontraba muy mal. Las investigaciones se centran en quién dejó abandonada a Fermina González al lado de la carretera sin conducirla a un hospital, a pesar del mal estado en que se encontraba. ${ }^{30}$

Derivado de la publicación de tal noticia, los padres de Fermina González demandaron en la vía civil a la Televisión Española solicitando la retractación respecto de la información publicada, así como el daño moral causado al honor de su hija. Las sentencias de los tribunales inferiores consideraron que dicho daño sí se había generado, por lo que como medio de retractación ordenaron que se publicara la sentencia, así como condenando a tal medio informativo al pago de 3.000.000 de pesetas. Ante tales resoluciones, el medio de comunicación interpuso amparo por considerarlas violatorias del derecho a la libertad de expresión, alegando que no cabe referir el honor, como derecho, a una persona fallecida.

Pese a ello, el Tribunal Constitucional español resolvió reconocerles a los padres de la fallecida el interés legítimo para alegar la violación del derecho fundamental de su hija, justificándolo de esta manera:

Parece indudable que en supuestos como el presente, en el que lo que se discute es si se atribuye a una persona ya fallecida su posible adicción a las drogas, la difamación no se detiene en el sujeto pasivo de la imputación, sino que alcanza también a aquellas personas de su ámbito familiar con las que guarda una estrecha relación. Como afirmábamos en la STC 231/1988, "no cabe dudar que ciertos eventos que puedan ocurrir a padres, cónyuges o hijos, tienen normalmente, y dentro de las pautas culturales de nuestra sociedad, tal trascendencia para el individuo, que su indebida publicidad o difusión incide directamente en la propia esfera de su personalidad". No debe dejarse tampoco en el olvido que, conforme posibilita el artículo 20.4 de la CE [reconocimiento constitucional del derecho al honor] y en el marco de los principios y valores que informan nuestra Norma fundamental, la Ley Orgánica 1/1982, del 5 de mayo, de Protección Civil del Derecho al Honor, a la Intimidad y a la Propia Imagen, establece que la memoria de una persona fallecida puede limitar el derecho a la comunicación de información veraz. 
Debemos concluir, en suma, que a la vista de los datos existentes en el momento de la publicación es sólo dudosamente veraz la información referida a la índole de las investigaciones y que, en cualquier caso, es indudablemente inveraz la noticia relativa al consumo de estimulantes de la fallecida. La radical distancia entre lo contrastado y lo publicado, y el demérito que la noticia suponía para una persona fallecida y para su familia, al sugerir la posible drogadicción de aquélla, conducen a negar el amparo de la información en la libertad constitucional que la protege, y a afirmar la corrección esencial de las ponderaciones judiciales que condujeron a la condena del recurrente. ${ }^{31}$

No pasa desapercibido que en el caso en comento, el interés legítimo reconocido por el Tribunal no fue propiamente un interés que sirviera para la entrada al proceso de amparo, es decir, no se trató de un caso de interés legítimo activo (al menos en sede de control constitucional); no obstante, el caso es ejemplificativo desde el punto de vista del interés legítimo pasivo, ya que el máximo intérprete de la Constitución española, no reparó en confirmar lo que ya habían resuelto los tribunales inferiores, quienes en primera y segunda instancia, sí habían reconocido la legitimación activa suficiente a los padres de la fallecida para solicitar la retractación por parte del medio de comunicación, así como reparación del daño moral (en sede de control de legalidad).

Ahora bien, respecto del temor que pudiera surgir en torno a que el interés legítimo se convierta en una herramienta que se utilizará únicamente para solicitar el pago de cuantiosas indemnizaciones, y con ello, un factor que generará la mercantilización de la justicia, cabe señalar que en torno a este tipo de casos, el Tribunal Constitucional ha sido muy cuidadoso en no reconocer legitimación en amparo a quien, con la invocación del interés legítimo, busca únicamente la defensa de derechos económicos.

Así, por ejemplo, en un caso similar al descrito, el Tribunal Constitucional español denegó la reclamación de parte de la heredera de una persona tetrapléjica que, antes de fallecer, había interpuesto un recurso de amparo invocando el derecho a la muerte eutanásica, lo cual nunca fue resuelto, razón por la cual la heredera pretendió reclamar una indemnización en favor de la herencia. En este caso, y a pesar de que el Tribunal confirmaba su criterio relativo al interés legítimo, en el

${ }^{31}$ STC 190/1996 extractos 1 y 4. 
sentido de que: “...en presencia de acciones procesales encaminadas al reconocimiento y defensa de ciertos derechos de la personalidad, [se] permite la continuidad en su ejercicio por los herederos y otraspersonas, una vez fallecido el que demanda...", 32 no menos cierto es que "... ante una acción de carácter personalísimo (...) no cabe, por tanto, la continuidad o sucesión procesal instada con el único soporte del título de heredera mortis causa del demandante originario". ${ }^{33}$

Lo trascendente de este fallo, no sólo es el límite que debe tener el interéslegítimo ante casos claramente mercantilizados - aducido por el Tribunal-, sino lo que es más, la puntualización de cuáles son los requisitos que deben de cumplirse para que un familiar pueda sustituirse — vía el interés legítimo - en la acción de amparo iniciada por una persona fallecida. El Tribunal refirió lo siguiente:

En efecto, la continuidad procesal (...) se halla caracterizada por dos notas: a) Se trata de derechos y relaciones jurídicas que no se agotan en sí mismos, sino que se proyectan sobre el grupo familiar, trascendiendo de su titular, siendo aquél el concernido por la decisión judicial de reconocimiento o de reparación del derecho lesionado, y, esencialmente, b) que, como ha puesto de relieve un sector doctrinal, no se produce en estos casos un llamamiento de los continuadores de la acción ya emprendida, o sucesores procesales, a título "iure successionis" sino "ope legis", en tanto que el legislador así lo ha dispuesto expresamente. ${ }^{34}$

Lo anterior marca un parámetro muy importante en tratándose de la procedencia del amparo vía interés legítimo: los familiares de una persona fallecida sólo podrían acudir al amparo, o continuar con su tramitación, cuando los derechos exigidos trasciendan al titular de los mismos $\mathrm{y}$, derivado de su violación, tengan impacto en el grupo familiar.

32 ATC 242/1998, fundamento jurídico 4.

33 Idem.

34 Idem. 


\section{B. Profesores de la Universidad de Sevilla}

vs. Estatutos Universitarios. STC 217/1992

(1o. de diciembre de 1992)

En este caso, catorce personas, en su calidad de profesores de la Universidad de Sevilla, interpusieron demanda de amparo en contra de algunos artículos de los Estatutos de la citada Universidad, aduciendo dos concretas violaciones: (i) vulneración del derecho fundamental a la libertad de cátedra (garantizado en el artículo 20.1 de la Constitución española) por cuanto no se les reconocía libertad para determinar el contenido de los exámenes, y (ii) la violación a los principios de igualdad y participación democrática (garantizados en los artículos 14 y 23 de la CE) debido a que, a su dicho, los Estatutos preveían un sistema electoral para la representación estudiantil que no daba opción a la representación de las minorías.

Por lo que hace al primero de los planteamientos, y tomando en consideración que no existió objeción alguna respecto de la legitimación por parte de los profesores para hacer dicho planteamiento, lo cual resulta obvio ya que estaban aduciendo la violación de un derecho del cual son titulares de manera personal y directa (libertad de cátedra), me limitaré a mencionar que el Tribunal Constitucional español, dando alcance a tal derecho fundamental, señaló que "...la libertad de cátedra no puede identificarse, obvio es decirlo, con el derecho de su titular a autorregular íntegramente y por sí mismo la función docente en todos sus aspectos, al margen y con total independencia de los criterios organizativos de la dirección del centro universitario...". ${ }^{35}$ Con ello se desestimaba este primer alegato.

Ahora bien, por lo que hace al segundo de los planteamientos, el Tribunal Constitucional español tuvo que realizar un examen previo respecto de la legitimación con la que contaba el grupo de profesores, debido a que los representantes de la Universidad de Sevilla alegaron que los profesores carecían de la misma para reclamar vía amparo el sistema electoral para la representación estudiantil debido a que no eran estudiantes.

35 STC 217/1992, fundamento jurídico 3. 
De esta forma, el Tribunal decidió reconocer al grupo de profesores el interés legítimo para reclamar tal sistema electoral estudiantil, lo que justificó de la siguiente manera:

5. Queda, finalmente, por examinar la alegada vulneración de los artículos 14 y 23.2 de la CE que se imputan al artículo 237.2 de los mismos Estatutos de la Universidad de Sevilla.

Con carácter previo, es preciso dar respuesta a la objeción que formula la representación de la Universidad de Sevilla respecto de la legitimación de los recurrentes ara impetrar el referido amparo ante este Tribunal. Nada impide, en efecto, que, aun habiendo sido admitido a trámite el recurso, este Tribunal pueda apreciar con ocasión de dictar Sentencia la concurrencia en la demanda planteada de defectos procesales insubsanables determinantes de la inviabilidad de un pronunciamiento sobre el fondo de la cuestión planteada. De esto modo, es preciso examinar y adoptar un pronunciamiento sobre la legitimación de los recurrentes para interponer recurso de amparo frente al artículo 237.2 de los Estatutos.

Ciertamente la titularidad de los derechos fundamentales presuntamente vulnerados por la disposición administrativa impugnada — los reconocidos en los artículos 14 y 23.2 de la CE - no corresponde a los recurrentes, todos ellos profesores de la Universidad de Sevilla, sino a los estudiantes de la mencionada Universidad. Con todo, no cabe negar a los actores la posibilidad de invocar en este caso un interés legítimo que les legitima a la luz del artículo 162.1 b) de la CE para interponer el presente recurso de amparo, máxime teniendo presente la flexibilidad con la que este Tribunal ha venido interpretando y exigiendo este requisito procesal.

En efecto, la fórmula electoral utilizada en la elección de los representantes de los estudiantes en el Claustro de la Universidad puede condicionar la composición de una parte y por ende del conjunto de este órgano de gobierno universitario. En consecuencia, no puede negarse a los miembros de uno de los sectores representados en este órgano colegiado un interés legítimo respecto de las medidas que afectan a la composición de ese órgano a cuya acción de gobierno quedan, por otra parte, sometidos. ${ }^{36}$

Como ya se ha mencionado, la actualización del interés legítimo depende — según la reforma constitucional al artículo 107 de la Constitución mexicana- de la existencia de un acto que viole los derechos reconocidos por la misma y que con ello se afecte la esfera jurídica de

${ }^{36}$ STC 217/1992, fundamento jurídico 5. 
un particular en virtud de su especial situación frente al orden jurídico. El presente caso resulta ejemplificativo para entender tal expresión, ya que la razón por la que el Tribunal Constitucional español decidió reconocer legitimación al grupo de profesores fue, precisamente, el hecho de que en última instancia la fórmula electoral impugnada sirve para la elección de los representantes estudiantiles en el Claustro de la Universidad, órgano de gobierno de todos los universitarios, incluidos claro está, los profesores de esa casa de estudios. Así, aunque no haya afectación personal y directa (interés jurídico) la legitimación se produce por la especial situación de los maestros frente al orden jurídico universitario (interés legítimo). Dicho sea de paso, el Tribunal no encontró probado el cargo de inconstitucionalidad del sistema electoral universitario, por lo que en este asunto, los dos planteamientos del grupo de demandantes fue desestimado por el Tribunal Constitucional español.

\section{Violeta Friedman vs. Revista "Tiempo". STC 214/1991 (11 de noviembre de 1991)}

Este caso resulta muy interesante por su contenido, debido a que nos permite observar hasta dónde puede llegar el interés legítimo. La señora Violeta Friedman interpuso amparo en contra de las sentencias de los tribunales de primera y segunda instancias, así como en contra de la sentencia que recayó sobre el recurso de casación, según las cuales, tales tribunales no reconocieron legitimación de la demandante para alegar la violación de su derecho al honor.

La señora Friedman, mujer de raza judía, consideró vulnerado tal derecho derivado de las declaraciones de León Degrelle un ex jefe de la Waffen S.S. (cuerpo de combate de élite de las Schutzstaffel durante la Segunda Guerra Mundial), recogidas en una revista en las que ridiculizaba el holocausto. En el número 168 de la revista Tiempo, correspondiente a la semana del 29 de julio al 4 de agosto de 1985, se publicó un reportaje titulado "Cazadores de nazis vendrán a España para capturar a Degrelle", en el cual Degrelle realizó las siguientes declaraciones:

¿Los judíos? Mire usted, los alemanes no se llevaron judíos belgas, sino extranjeros. Yo no tuve nada que ver con eso. Y evidentemente, si hay tantos ahora, resulta difícil creer que hayan salido tan vivos de los hornos crematorios. El problema con los judíos — matiza Degrelle- es 
que quieren ser siempre las víctimas, los eternos perseguidos, si no tienen enemigos, los inventan. Falta un líder; ojalá que viniera un día el hombre idóneo, aquél que podría salvar a Europa... Pero ya no surgen hombres como el Fürher... Han sacado los huesos y hasta los dientes de Mengele... ¡Hasta dónde llega el odio! A mi juicio, el doctor Mengele era un médico normal y dudo mucho que las cámaras de gas existieran alguna vez... ${ }^{37}$

Así las cosas, la señora Friedman formuló demanda de protección civil del derecho al honor, señalando que ...las citadas declaraciones habían lesionado el honor de la actora judía, quien estuvo internada en el campo de exterminio de Auschwitz, donde murió gaseada toda su familia por orden de un médico citado en las declaraciones, por cuanto que con tales afirmaciones el demandado no sólo tergiversaba la Historia, sino que, además, llamaba mentirosos a quienes, como la demandante, padecieron los horrores de los campos de concentración nazis... ${ }^{38}$

Los tribunales inferiores resolvieron negar la legitimación activa a la señora Friedman aduciendo

...de una parte, que la actora no está legitimada para la protección de su honor no atacado en el reportaje porque ninguna de las expresiones se referían concretamente a ella, pues ni se le nombraba ni aludía personalmente (...) Y, de otra parte, que las declaraciones del señor Degrelle estaban amparadas por el derecho a la libertad de expresión consagrado en el artículo 20.1 de la CE... ${ }^{39}$

Pese a lo anterior, y aun cuando en tres ocasiones diferentes (primera instancia, apelación y casación) se le negó el interés legítimo a la señora Friedman, el Tribunal Constitucional español le reconocía la legitimación activa razonándolo de la siguiente manera:

5. Tratándose de un derecho personalísimo, como es el honor, la legitimación activa corresponderá, en principio, al titular de dicho derecho fundamental. Esta legitimación originaria no excluye, ni la existencia de otras legitimaciones (...) ni que haya de considerarse también como legitimación originaria la de un miembro de un grupo étnico o social deter-

37 STC 214/1991, antecedente 2.

38 Idem.

39 Idem. 
minado, cuando la ofensa se dirigiera contra todo ese colectivo, de tal suerte que, menospreciando a dicho grupo socialmente diferenciado, se tienda a provocar en el resto de la comunidad social sentimientos hostiles o, cuando menos, contrarios a la dignidad, estima personal o respeto al que tienen derecho todos los ciudadanos con independencia de su nacimiento, raza o circunstancia personal o social...

10. El significado personalista que el derecho al honor tiene en la Constitución no impone que los ataques o lesiones al citado derecho fundamental, para que tengan protección constitucional, hayan de estar necesariamente perfecta y debidamente individualizados "ad personam", pues, de ser así, ello supondría tanto como excluir radicalmente la protección del honor de la totalidad de las personas jurídicas, incluidas las de substrato personalista, y admitir, en todos los supuestos, la legitimidad constitucional de los ataques o intromisiones en el honor de personas, individualmente consideradas, por el mero hecho de que los mismos se realicen de forma innominada, genérica o imprecisa. ${ }^{40}$

Así, y una vez que el Tribunal Constitucional reconocía el interés legítimo a la demandante, resolvía declarar nulas las sentencias inferiores atendiendo a los siguientes argumentos:

11. Ni la libertad ideológica (artículo 16 de la CE) ni la libertad de expresión (artículo 20.1 de la CE) comprenden el derecho a efectuar manifestaciones, expresiones o campañas de carácter racista o xenófobo, puesto que, tal como dispone el artículo 20.4, no existen derechos ilimitados y ello es contrario, no sólo al derecho al honor de la persona o personas directamente afectadas, sino a otros bienes constitucionales como el de la dignidad humana (artículo 10 de la CE), que han de respetar, tanto los poderes públicos, como los propios ciudadanos. La dignidad como rango o categoría de la persona como tal, del que deriva y en el que se proyecta el derecho al honor (artículo 18.1 de la CE), no admite discriminación alguna por razón de nacimiento, raza o sexo, opiniones o creencias.

12. De la conjunción de ambos valores constitucionales, dignidad e igualdad de todas las personas, se hace obligado afirmar que, ni el ejercicio de la libertad ideológica, ni la de expresión pueden amparar manifestaciones o expresiones destinadas a menospreciar o a generar sentimientos de hostilidad contra determinados grupos étnicos, de extranjeros o inmigrantes, religiosos o sociales, pues en un Estado como el español, social, democrático y de derecho, los integrantes de aquellas colectividades tie-

STC 214/1991, fundamentos jurídicos 5 y 10. 
nen el derecho a convivir pacíficamente y a ser plenamente respetados por los demás miembros de la comunidad social. ${ }^{41}$

Este es un claro ejemplo de lo que a lo largo de estas líneas he intentado hacer ver: el interés legitimo posibilita que el proceso, flexibilizando su entrada, se ponga al servicio de los derechos, ya que más allá de que se otorgue o no la razón al demandante, permite el análisis de los planteamientos de inconstitucionalidad y, llegado el caso, el otorgamiento del amparo y protección por parte de la magistratura constitucional - tal y como ocurrió en este caso-; de no ser el caso, no habrá amparo, pero al menos, el demandante tendrá una respuesta de fondo a sus pretensiones.

\section{Confederación Sindical de Comisiones Obreras de Euskadi vs. Diputación Foral de Guipúzcoa. STC 24/2001 (29 de enero de 2001)}

En este caso, el sindicato en mención promovió amparo en contra de la sentencia de la Sala Contencioso-Administrativa del Tribunal Superior de Justicia del País Vasco que inadmitió su demanda contra la Diputación Foral de Guipúzcoa por las bases de un concurso de oposición para cubrir doce plazas de bomberos, debido a que a dicho del mencionado sindicato, el establecimiento de pruebas físicas únicas para todos los aspirantes, suponía una infracción del derecho a la igualdad por razón de sexo, pues las pruebas de aptitud física deberían establecerse de conformidad con las características propias de cada sexo, ya que en caso contrario las mujeres se encontrarían en peores condiciones para acceder a las referidas plazas, al haberse establecido las pruebas físicas atendiendo a un promedio masculino sin evidencia de que las mismas sean realmente necesarias para el desempeño del trabajo, y sin que tampoco se recojan otras aptitudes que en mayor medida corresponden a las mujeres.

Por lo que hace a la legitimación, el tribunal inferior desestimó la demanda debido a que consideró que:

...la función constitucionalmente atribuida a los sindicatos no alcanza a transformarlos en guardianes abstractos de la legalidad, cualesquiera

41 Ibidem, fundamentos jurídicos 11 y 12. 
que sean las circunstancias en que ésta pretenda hacerse valer. En suma, la legitimación de los sindicatos en el ámbito de lo contencioso-administrativo, en cuanto aptitud para ser parte en un proceso concreto o legitimación ad causam ha de localizarse en la noción de interés profesional o económico; interés que ha de entenderse referido en todo caso a un interés en sentido propio, cualificado o específico (STC 97/1991, fundamento jurídico 2). Interés que doctrinal y jurisprudencialmente viene identificado en la obtención de un beneficio o la desaparición de un perjuicio en el supuesto de que prospere la acción intentada y que no necesariamente ha de revestir un contenido patrimonial. ${ }^{42}$

Pese a tal argumentación, el Tribunal Constitucional comenzó por establecer los requisitos que, desde su visión, debe cubrir cualquier sindicato para ostentar válidamente un interés legítimo, señalando que:

En caso similar al actual en cuanto al problema de la legitimación la STC 101/1996, del 13 de mayo, en su FJ 2 hace una doble precisión: en primer lugar, un reconocimiento abstracto o general de la legitimación sindical para impugnar ante lo contencioso-administrativo decisiones que afecten a los trabajadores, $y$, en segundo lugar, establece una exigencia de concreción de dicha capacidad genérica en cada uno de los pleitos que entablen. ${ }^{43}$

Dicho lo anterior, y por lo que hace al primero de los requisitos mencionados, el Tribunal lo consideró cubierto bajo la siguiente lógica:

Respecto de lo primero (...) la legitimación del sindicato recurrente es, pues, indiscutible. Como afirmamos en la STC 210/1994, los sindicatos desempeñan, tanto por el reconocimiento expreso de la Constitución (artículos 7 y 28) como por obra de los tratados internacionales suscritos por España en la materia (por todos, Pacto Internacional de Derechos Económicos, Sociales y Culturales, artículo 8o. o artículo 5o., parte II, de la Carta Social Europea), una función genérica de representación y defensa de los intereses de los trabajadores que, como ya ha sostenido la doctrina de este Tribunal, no descansa sólo en el vínculo de la afiliación, sino en la propia naturaleza sindical del grupo. La función de los sindicatos, pues, desde la perspectiva constitucional no es únicamente la de representar a

42 STC 24/2001, antecedente 2.c.

43 Ibidem, fundamento jurídico 5 . 
sus miembros, a través de los esquemas del apoderamiento y de la representación del derecho privado.

Cuando la Constitución y la Ley los invisten con la función de defender los intereses de los trabajadores, les legitiman para ejercer aquellos derechos que, aun perteneciendo en puridad a cada uno de los trabajadores ut singulus, sean de necesario ejercicio colectivo (...) Por esta razón, es posible reconocer en principio legitimado al sindicato para accionar en cualquier proceso en que estén juego intereses colectivos de los trabajadores...44

Ahora bien, por lo que hace al segundo de los requisitos, aquél consistente en que el reconocimiento abstracto o general de la legitimación sindical debe concretarse en cada caso que sea planteado por un sindicato ante la jurisdicción, el Tribunal lo consideró cubierto bajo la siguiente lógica:

...como segundo dato esencial (...) se afirma la necesidad de que la legitimación otorgada (...) y reconducible a la relevancia constitucional de los sindicatos, se proyecte de un modo particular sobre el objeto de los recursos que éstos entablen ante los Tribunales: Esa capacidad abstracta del sindicato tiene que concretarse, en cada caso, mediante un vínculo o conexión entre la organización que acciona y la pretensión ejercitada. La función constitucionalmente atribuida a los sindicatos no alcanza a transformarlos en guardianes abstractos de la legalidad, cualesquiera que sean las circunstancias en que ésta pretenda hacerse valer (...) Se trata, en definitiva, de aplicar a estas personas jurídicas particulares la misma regla que se aplica a cualquier otra persona física o jurídica para reconocerle la posibilidad de actuar en un proceso: tener interés legítimo en él. Por tanto (...) su legitimación en el ámbito de lo contencioso-administrativo, en cuanto aptitud para ser parte en un proceso concreto, o legitimatio ad causam, ha de localizarse en la noción de interés profesional o económico; interés que ha de entenderse referido en todo caso a un interés en sentido propio, cualificado o específico...

En el caso actual, en que la proyección general del acto recurrido y la índole de la vulneración constitucional que se le imputa resultan más claras, unido a la notoria condición de sindicato más representativo del recurrente permite incluir la impugnación de dicho acto (...) y por ello como parte del interés profesional o económico cuya defensa tiene ins-

44 Idem. 
titucionalmente confiada, por cuanto lo que está realmente en juego en el proceso a quo es un indudable interés colectivo [por lo que se] otorga al Sindicato recurrente la legitimación negada en la sentencia recurrida. ${ }^{45}$

Así, el Tribunal Constitucional español resolvía otorgar el amparo solicitado por el sindicato Confederación Sindical de Comisiones Obreras de Euskadi y, derivado de ello, declarar que se había vulnerado su derecho a la tutela judicial efectiva, razón por la que ordenó anular la sentencia del Tribunal Superior de Justicia del País Vasco, retrotrayendo las actuaciones al momento procesal previo al dictado de la sentencia.

De esta manera puede afirmarse que la doctrina jurisprudencial española, en torno al interés legítimo de los sindicatos, consiste en su reconocimiento como entes legitimados para accionar cualquier proceso en el que estén en juego intereses colectivos de los trabajadores, pero señalando que la legitimación a ellos otorgada debe concretarse en cada caso mediante un vínculo o conexión entre la organización sindical que acciona ( $v$. gr. sus funciones u objetivos) y la pretensión ejercitada, de ahí que también sea conveniente afirmar que el interés legítimo no les alcanza a los sindicatos para transformarse en guardianes abstractos de la legalidad. Esta última modulación del instituto jurídico objeto de nuestro análisis resulta fundamental de cara a las organizaciones sindicales, y como se verá, a cualquier otra organización que ostente algún tipo de representación colectiva.

\section{E. Asociación Acción Familiar vs. Real Decreto} sobre interrupción del embarazo. ATC 13/1989 (16 de enero de 1989)

Derivado del caso previamente analizado, relativo al interés legítimo de los sindicatos, considero que resultará muy importante analizar un caso en el que dicho instituto jurídico lo aduce una organización de la sociedad civil. Esto nos permitirá advertir cuál es el alcance de lo que hasta ahora ya sabemos que dice el Tribunal Constitucional español respecto de las organizaciones que ostenten algún tipo de representación colectiva: la legitimación otorgada debe concretarse en cada caso me-

45 Idem. 
diante un vínculo o conexión entre la organización que acciona y la pretensión ejercitada.

La Asociación Acción Familiar interpuso demanda de amparo contra la sentencia del Tribunal Supremo español recaída en el recurso contencioso-administrativo interpuesto en contra del Real Decreto 2.409/1986 relativo a los Centros acreditados y dictámenes preceptivos para la práctica de la interrupción del embarazo. La demanda se fundaba en la consideración de que el decreto impugnado era nulo y contrario al artículo 15 de la Constitución Española (todos tienen derecho a la vida y a la integridad física y moral) por no prever las debidas garantías para la vida y salud de las madres gestantes y de los nasciturus sin malformaciones, así como por facilitar la realización de abortos en casos no admisibles legalmente.

El Tribunal Supremo español, al dictar su sentencia, negó la legitimación a la Asociación Acción Familiar para litigar en representación de las mujeres gestantes, considerando, además, que los problemas suscitados respecto al contenido del decreto impugnado no vulneran derechos fundamentales. Es por ello que la asociación de mérito acudiría ante el Tribunal Constitucional a fin de demandar el amparo sobre la base de que se había violado su derecho a la tutela judicial efectiva porque el Tribunal Supremo le negó la legitimación para defender los derechos de las mujeres gestantes.

Sobre este particular, el Tribunal Constitucional español razonó lo siguiente:

Es claro que la Asociación demandante no es titular del derecho fundamental reconocido en el artículo 15 de la Constitución. Pero para interponer el recurso de amparo no sólo están legitimados los titulares del derecho fundamental invocado, sino, como dispone el artículo $162.1 \mathrm{~b}$ ) de la Constitución, "toda persona natural o jurídica que invoque un interés legítimo".

Ahora bien, según ha declarado este Tribunal en reiteradas ocasiones (SSTC 60/1982, del 11 de octubre, y 67/1986, del 22 de mayo; ATC 139/1985, del 27 de febrero, entre otras resoluciones), este concepto de interés legitimo es diferente y más amplio que el de interés directo $\mathrm{y}$, más aún, que el concepto de derecho subjetivo, aunque no puede dejar de entenderse como un interés en sentido propio, cualificado o especifico, ya sea de carácter individual o colectivo. Por eso, y aun ratificando la precisión efectuada por el Tribunal Supremo, según la que la Asociación 
Acción Familiar no puede ostentar la representación procesal de las mujeres gestantes que pretendan acogerse a la disposición recurrida, tampoco puede negarse a dicha Asociación la legitimación activa para impugnar en amparo un Real Decreto relativo a centros sanitarios acreditados y dictámenes preceptivos para la práctica legal de la interrupción voluntaria del embarazo, ya que, al tener dicha Asociación como fin estatutario la defensa del derecho a la vida "en especial frente al aborto y la eutanasia", es evidente que dicho fin se halla en relación de afectación directa con el objeto del proceso y que, al impugnar la disposición recurrida, la Asociación mencionada defiende un interés legitimo propio y específico que, en el presente caso, coincide con la defensa dederechos fundamentales ajenos supuestamente infringidos por aquélla. ${ }^{46}$

De esta manera, el presente caso sirve de base para advertir, tal y como lo había mencionado, cuál es el alcance del interés legítimo respecto de las organizaciones que ostenten algún tipo de representación colectiva, y concretamente, qué se quiere decir cuando se afirma que la legitimación otorgada debe concretarse en cada caso mediante un vínculo entre la organización que acciona y la pretensión ejercitada. La respuesta ahora es clara: la actualización del interés legítimo de una persona moral dependerá de la conexión entre el objeto del proceso y los fines para los que la asociación fue creada.

Así, en este caso, señaló que:

...al tener dicha Asociación como fin estatutario la defensa del derecho a la vida "en especial frente al aborto y la eutanasia", es evidente que dicho fin se halla en relación de afectación directa con el objeto del proceso y que, al impugnar la disposición recurrida, la Asociación mencionada defiende un interés legítimo propio y específico... ${ }^{47}$

Por lo demás, cabe señalar que en el presente caso, el Tribunal Constitucional español declaró inadmisible el amparo

...dado que el Real Decreto 2.409/1986 no ha podido originar, por sí mismo, las violaciones del artículo 15 de la Constitución que la demandante alega [ya que] se limita a establecer los requisitos que deben reunir los centros sanitarios privados para poder ser acreditados para la

${ }^{46}$ ATC 13/1989, fundamento jurídico 3.

${ }^{47}$ Idem. 
práctica de determinados tipos de interrupción del embarazo, pero siempre "a los efectos de lo dispuesto en el artículo 417 bis del Código Penal" [es decir] que exista o no una extralimitación de estos límites penales y, por consiguiente, de los límites derivados del artículo 15 de la Constitución, no depende del Real Decreto 2.409/1986 en sí mismo, sino de una eventual aplicación incorrecta e infractora del mismo, que, en su caso, siempre podría ser denunciado ante los órganos judiciales competentes e incluso, subsidiariamente, en la vía del amparo constitucional. ${ }^{48}$

\section{F. Asociación de Profesores de Religión}

vs. Subsecretario de Educación. STC 47/1990 (23 de marzo de 1990)

Este precedente los abordaremos con la intensión de precisar, aún más, cuál puede llegar a ser el alcance de uno de los requisitos que el Tribunal Constitucional español ha entendido como indispensable para que se actualice el interés legitimo en tratándose de personas morales que ostentan algún tipo de representatividad. Como se vio en el caso anterior, el Tribunal señaló que tal actualización dependerá de la conexión entre el objeto del proceso y los fines para los que la asociación fue creada. Sin embargo, cabe hacernos la siguiente pregunta: ¿qué tan estrecha tiene que ser tal conexión o vinculación?

La pregunta no resulta sencilla de cara a casos como el que se analiza. La Asociación de Profesores de Religión de Centros Estatales interpuso demanda de amparo contra la instrucción del Subsecretario de Educación y Ciencia por la que se prohibía que los Profesores de Religión pudieran ser candidatos al cargo de Director de sus respectivos Centros. Así, y tomando en consideración que los derechos fundamentales implicados en el caso serían los de igualdad, de no discriminación y de libertad religiosa, prima facie parecería ser que la legitimación para acudir vía interés legítimo al amparo la podrían llegar a acreditar - en todo caso- organizaciones cuyos fines fueran esos: la promoción de la igualdad, la erradicación de la discriminación o la promoción de la libertad religiosa.

Sin embargo, el Tribunal Constitucional español, atendiendo a la extensión y flexibilidad con la que - a su dicho- debe entenderse el interés legítimo, le reconoció legitimación activa a la asociación en

48 ATC 13/1989, fundamento jurídico 4. 
cuestión debido a que dentro de sus fines sociales o estatutarios se encontraba la promoción profesional de sus miembros, promoción la cual era obstaculizada, según la persona moral demandante, por la instrucción del Subsecretario de Educación y Ciencia. El Tribunal Constitucional español lo razonó de la siguiente manera:

Si bien es cierto que no se tiene legitimación activa para interponer un recurso de amparo por el solo hecho de haber sido parte en el proceso judicial correspondiente (...) sino que es necesario invocar el interés legítimo de la persona natural o jurídica que lo promueva (...) no lo es menos que no puede confundirse este concepto de interés legítimo con el más restrictivo de la titularidad personal del derecho fundamental o libertad pública cuyo amparo se pide ante este Tribunal. El interés legítimo a que alude el artículo 162.1 b) de la Constitución es un concepto más amplio que el de interés directo, según declaramos en la STC 60/1982, y, por tanto, de mayor alcance que el de derecho subjetivo afectado o conculcado por el acto o disposición objeto del recurso.

Sin necesidad de definir ahora en toda su extensión aquel concepto de interés legítimo, es evidente que en el mismo hay que entender incluido el interés profesional de promoción y defensa de una categoría de trabajadores, del que puede ser titular no sólo cada uno de ellos, individualmente considerados, sino también cualquier asociación o Entidad que haya asumido estatutariamente esos mismos fines (...) Así ocurre en el presente caso en que la Asociación de Profesores de Religión de Centros Estatales impugna una Instrucción y una resolución judicial que considera lesivas de derechos fundamentales de sus miembros, a los que atañen directamente, y que afectan también directamente a la promoción profesional de los mismos, lo que constituye un fin estatutario de la Asociación. De ahí que no pueda negarse a la demandante la legitimación para interponer este recurso de amparo. ${ }^{49}$

No obstante lo anterior, aun cuando el Tribunal ampliaba así su concepción del interés legítimo, resolvía desestimar la demanda de amparo debido a que:

...la Constitución no confiere a ningún ciudadano el derecho a ocupar determinadas funciones y cargos públicos y no impide, antes bien prevé expresamente, que puedan establecerse en cada caso ciertos requisitos 
para acceder a los mismos [los cuales] por imperativo del principio de igualdad (...) han de tener una justificación objetiva y razonable..., ${ }^{50}$ para no resultar discriminatorios.

Lo anterior fue así entendido por el Tribunal Constitucional español debido a que los candidatos a directores de los centros educativos debían ser: (i) profesores con destino definitivo en el Centro (con plena estabilidad laboral); (ii) con al menos un año de permanencia en el mismo, y (iii) con tres años de docencia en los Centros del nivel docente de que se trate; requisitos los cuales, atendiendo al sistema de asignación y nombramiento de los profesores de religión, ${ }^{51}$ eran de imposible cumplimiento, razón por la cual se emitió la instrucción consistente en que no podían ser candidatos a director. En suma, la distinción no fue considerada discriminatoria debido a que no atendía al hecho de que fueran profesores de religión, sino al hecho de que por su movilidad laboral no resultaba conveniente que fueran designados directores.

Los dos últimos casos que analizaremos resultan altamente interesantes. Si bien son similares a los anteriores en el sentido de que han sido asuntos en los que son organizaciones las que alegan un interés legítimo para solicitar el amparo, se diferencian en que, de su análisis, puede advertirse una especie de conflicto de intereses debido a que de una parte, la persona moral pretende defender derechos fundamentales de alguna(s) persona(s), pero por la otra, esto lo han hecho aún a costa o en contra de los intereses de sus propios titulares. Así, de la revisión de estos precedentes podremos contestar una interrogante que resulta harto complicada de cara al interés legítimo: ¿puede una persona moral defender derechos fundamentales aun cuando el titular de los mismos no desee hacerlo?, ¿el interés legítimo debe cubrir este tipo de supuestos?

Veamos pues los siguientes dos casos que quizá nos sirvan para acercarnos a posibles respuestas:

50 Ibidem, extracto 4.

51 Cabe señalar que los profesores de religión son designados por la autoridad académica para cada año escolar, entre las personas que proponga el Ordinario diocesano, conforme estipula el artículo 3o. del Acuerdo entre el Estado español y la Santa Sede sobre enseñanza y asuntos culturales, ratificado el 4 de diciembre de 1979, por lo que es evidente que tales profesores no cumplen el requisito de destino definitivo en los Centros Educativos. 


\section{G. Ministerio Fiscal vs. Administración Penitenciaria. STC 11/1991 (17 de enero de 1991)}

En este caso, el amparo fue solicitado por el Ministerio Fiscal en contra el auto dictado en apelación por la Audiencia Provincial de Cáceres y el pronunciado por el Juzgado de Vigilancia Penitenciaria de dicha ciudad, por el que se acordó que el interno Joaquín Calero Arcones, quien se encontraba en huelga de hambre, no recibiera asistencia médica ni fuera alimentado forzadamente hasta que perdiera la conciencia o levantara voluntariamente su ayuno, por considerar que dichas resoluciones vulneraban el derecho fundamental a la vida, reconocido en el artículo 15 de la CE.

Es importante precisar que la decisión del Ministerio Fiscal de erigirse en guardián de la vida de Joaquín Calero Arcones ante el Juzgado de Vigilancia Penitenciaria, aun en contra de la propia voluntad del titular, fue justificada aduciendo que el derecho a la vida es un derecho superior a cualquier otro, absoluto, ilimitado y de especial protección, coexistiendo la obligación positiva del Estado de proteger la salud y la vida de todos los ciudadanos. ${ }^{52}$ Por ello sostuvo que lo procedente era alimentar forzadamente al interno debido a que su vida estaba en grave peligro.

Sin embargo, ante dicha petición, el juez en cuestión resolvió que era indefectible:

...respetar la libre y consciente voluntad del interno don Joaquín Calero Arcones de no ser asistido médicamente ni alimentado forzadamente hasta que, perdida su consciencia o por tomar una decisión contraria a la actual, precise que se le presten los auxilios médicos necesarios para la salvaguarda de su integridad física y moral [manifestando su disconformidad con el] Ministerio Fiscal, en cuanto éste reputa el derecho a la vida, consagrado en el artículo 15 de la Constitución, de superior rango al de la dignidad personal, lo que estima erróneo por, entre otras, "la sencilla razón lógica y de derecho natural — dice el auto del juez- de que el derecho a la vida contra la dignidad de la persona y frente al libre derecho del desarrollo de la personalidad resulta vacío y sin contenido". Entiende

52 Es importante mencionar que de acuerdo al artículo 43 de la CE, no sólo se reconoce el derecho a la protección de la salud, sino que se establece que "compete a los poderes públicos organizar y tutelar la salud pública a través de medidas preventivas y de las prestaciones y servicios necesarios. La ley establecerá los derechos y deberes de todos al respecto". 
que "en un orden de prelación de valores ha de primar el derecho fundamental de la dignidad frente al derecho a la vida". ${ }^{53}$

\section{Más allá del interesante debate iusfilosófico antes expuesto, ${ }^{54}$ lo} importante para efectos de nuestro objeto de estudio, es el hecho de que el Tribunal Constitucional español no reparó en reconocerle legitimación del Ministerio Fiscal, aún en contra de la voluntad del titular de

53 STC 11/1991, antecedente 2.

54 En un trabajo que realicé, so pretexto del debate en torno a la despenalización del aborto en México, cfr. Vázquez Gómez B., Francisco, "El voto de minoría a favor de la vida", en Montoya Rivero, Víctor Manuel y Ortiz Trujillo, Diana (coords.), En defensa de la vida: un voto de minoría sobresaliente, CMDH, 2010, pp. 167-216; pude comprobar cómo la Comisión Interamericana de Derechos Humanos ha sido enfática en el reconocimiento del carácter especial del valor de la vida humana, al punto de que le reconoce el estatus de jus-cogens. "El concepto jus-cogens se deriva de un orden superior de normas establecidas en tiempos antiguos y que no pueden ser contravenidas por las leyes del hombre o de las naciones. Esta postura ha sido ratificada recientemente por la propia Comisión Interamericana de Derechos Humanos al señalar que el derecho a la vida es ampliamente reconocido como el derecho supremo del ser humano y conditio sine qua non para el goce de todos los demás derechos". Cfr. Comisión Interamericana de Derechos Humanos, casos: Remolcadora 13 de marzo, 1996, párrafo 79; Sequieras Mangas c. Nicaragua de 1997, párrafo 145; y Edwards y otros c. Bahamas en 2001, párrafo 109), con lo cual se entiende que el valor de la vida humana deba ser considerada como una realidad pre-jurídica que se constituye en uno de los fundamentos de los derechos humanos. Véase Casas Martínez, María de la Luz et al., Bioética y aborto. Hacia una cultura de la vida, México, Trillas, 2009, pp. 87 y 88. Este tipo de precedentes confirman que resulta un error colocar en la misma balanza dos entidades que no son de la misma categoría, como por ejemplo el "derecho" a la vida y el derecho al libre desarrollo de la personalidad. Hablando con puridad filosófica, debemos afirmar que el derecho a la vida no existe, o si se prefiere, la vida no es un derecho. Nadie tiene derecho a la vida, todo ser humano está vivo ¡y punto! Otra cosa muy diferente es que, derivado de esa realidad pre-jurídica se reconozca en las Constituciones el derecho a la protección de la salud, el derecho a la protección de nuestra integridad física, el derecho a un medio ambiente adecuado, el derecho a la alimentación, el derecho de legítima defensa, etcétera. Por ello, sostiene Joseph Raz, la vida es un presupuesto para que podamos acceder a todas las cosas que tienen valor y ejercer todos nuestros derechos. Véase Raz, Joseph, Value, respect, and attachment, U.K., Cambridge University Press, 2001, p. 124, http://books.google.com.mx/. De ahí que se afirme que la vida humana es un valor, no un derecho, o si se prefiere, es fundamento de los derechos, por lo que debe ser considerado un límite exógeno a los actos de toda autoridad, legislador o juez. "Éste, al sentenciar, puede elegir entre dos derechos, pero no entre un derecho y algo que, por fundamentar los derechos todos, está en un nivel anterior, superior [y] diferente".Véase Pereira Menaut, Carlos-Antonio, Lecciones de teoría constitucional, México, PorrúaUniversidad Panamericana, 2005, p. 329. 
los derechos fundamentales implicados en el caso, sobre la base de lo establecido en el artículo 124 de la $\mathrm{CE}$, el cual señala que:

el Ministerio Fiscal, sin perjuicio de las funciones encomendadas a otros órganos, tiene por misión promover la acción de la justicia en defensa de la legalidad, de los derechos de los ciudadanos y del interés público tutelado por la ley, de oficio o a petición de los interesados, así como velar por la independencia de los Tribunales y procurar ante éstos la satisfacción del interés social.

Así, de una interpretación amplia y flexible de la legitimación con la que constitucionalmente cuenta el Ministerio Fiscal, relacionada con la doctrina jurisprudencial que sobre el concepto de interés legitimo ya se ha analizado, el Tribunal Constitucional español daba entrada al caso a fin de analizar los planteamientos de fondo, sin siquiera reparar en el hecho de que era el propio Joaquín Calero Arcones quien voluntariamente permanecía en huelga de hambre.

Posteriormente, aun cuando el Tribunal Constitucional consideró compatible con la Constitución y con los derechos fundamentales invocados, que la alimentación forzosa podía tener lugar una vez que la vida de los reclusos en huelga de hambre corriera grave peligro, resolvería negar el amparo sobre la base de que la autoridad competente para determinar el momento en que la vida de un interno corre grave peligro, era la Administración Penitenciaria, no el Ministerio Fiscal. ${ }^{55}$

H. Comité de Empresa vs. Previsión Española-Sur, S.A. STC 74/1996 (30 de abril de 1996)

Tal y como lo he mencionado, el análisis de estos dos últimos precedentes tiene por objeto contestar una interrogante que resulta muy complicada de cara al interés legítimo: ¿puede una persona moral defender derechos fundamentales aun cuando el titular de los mismos no desee hacerlo?, ¿el interés legítimo debe cubrir este tipo de supuestos? En este caso, aun cuando no lo hizo de una manera directa, el Tribunal Constitucional español respondió afirmativamente a nuestros cuestionamientos.

55 STC 11/1191, fundamento jurídico 4. 
La aseguradora Previsión Española-Sur, S. A., ofreció a sus trabajadores la posibilidad de modificar, de modo individual, el horario de jornada que venían prestando. Cabe señalar que la empresa se regía por un contrato colectivo de ámbito estatal para empresas de seguros y reaseguros cuyo artículo 7 establecía que la modificación de la jornada continua (única prevista en el Convenio) sólo podría hacerse respetando el número de horas establecidas, a través de los delegados de personal o comités de empresa, y por acuerdo unánime de todos los trabajadores en cada centro de trabajo afectado. En razón de lo anterior, el Comité de Empresa (órgano de representación de los empleados en el seno de la empresa y por ello diverso a los sindicatos), se presentó ante los tribunales llegando el asunto hasta el Tribunal Constitucional español.

Como puede advertirse, es claro el conflicto de intereses que se presenta, ya que por un lado el Comité de Empresa denunciaría el incumplimiento del contrato colectivo en tratándose de la modificación del horario laboral, pero por el otro, habían sido los propios trabajadores los que en lo individual habían accedido a dicha modificación.

El Tribunal negaría el reconocimiento de interés legítimo al Comité de Empresa, pero indirectamente se lo reconocería a las organizaciones sindicales, es decir, si bien no reconoció la legitimación al demandante, el Tribunal Constitucional fue claro en advertir que en casos como el planteado, sí podría existir interés legítimo pero no a favor de los Comités de Empresas sino a favor de los sindicatos. De ahí que señalara líneas arriba que el Tribunal Constitucional español, aun cuando no lo hizo de una manera directa, respondía afirmativamente a nuestros cuestionamientos.

El Tribunal lo razonó así:

5. No obstante lo anterior, aún es preciso plantearse si, en el asunto que nos ocupa, concurre en el actor el "interés legítimo" a que se refiere el artículo 162.1 b) de la Constitución.

A estos efectos, es claro que, con independencia de que el Comité de Empresa se encuentre o no "sindicalizado", no forma parte de su función representativa de los trabajadores y de las demás facultades que legalmente le son atribuidas (...) la de velar y defender la posición que constitucionalmente se atribuye a los sindicatos (artículos 7 y 28.1 de la $\mathrm{CE}$ ) en el ámbito de las relaciones laborales y, en particular, en la esfera de la negociación colectiva, máxime cuando se trata de un Convenio de 
ámbito nacional que exclusivamente puede ser negociado por organizaciones sindicales (artículo 87.2 E.T.). Cierto es (...) que los Comités de Empresa pueden plantear conflictos colectivos y defender los intereses de los trabajadores a los que representan [sin embargo] en circunstancias como la presente, de colisión entre la autonomía individual y el sistema de negociación colectiva, sólo las organizaciones sindicales, titulares del derecho reconocido en el artículo 28.1 de la CE, pueden tener "interés legítimo" en la defensa, ante este Tribunal, de la eficacia de los Convenios como contenido indirecto de la libertad sindical, pues sólo a ellos corresponde reaccionar, en este contexto, frente a eventuales conductas antisindicales de esta naturaleza.

Este Tribunal ya ha declarado que, ciertamente, no es descartable la hipótesis de que, a través de pactos favorecedores suscritos individualmente entre trabajadores y empresa, se cobije una estrategia patronal destinada a mermar la posición preferente que en el ámbito de la mediación laboral corresponde por mandato constitucional a las organizaciones sindicales (STC 208/1993). Ahora bien, en tales supuestos, sólo los sindicatos - suscribieran o no el Convenio- pueden valorar esa situación y, en su caso, reaccionar jurisdiccionalmente en defensa del derecho a la libertad sindical. En conclusión, el recurrente, que acciona en su condición de Presidente de un Comité de Empresa, carece de legitimación ex artículo 162.1 b) de la Constitución para defender, en el caso presente, la eventual vulneración del derecho fundamental a la libertad sindical que denuncia. ${ }^{56}$

De esta forma, el Tribunal denegaba el amparo solicitado al Comité de Empresa debido a la falta de interés legítimo, ya que a dicho de la mayoría, no se había actualizado uno de los supuestos necesarios para el reconocimiento de legitimación en este tipo de casos: el vínculo o conexión entre la organización que acciona y la pretensión ejercitada, ya que constitucionalmente la defensa del derecho a la libertad sindical sólo le compete a los sindicatos, no así a los Comités de Empresa.

No obstante, sobre esta resolución, recayó voto particular del magistrado Manuel Jiménez de Parga y Cabrera, mismo que rescataré brevemente debido a que se apartó de la decisión mayoritaria, precisamente, por lo que hace a la cuestión del interés legítimo y la posterior denegación del amparo. Dicho magistrado discrepó en el tenor siguiente:

56 STC 74/1996, fundamento jurídico 5. 
La Sentencia de la mayoría deniega el amparo solicitado por el Presidente de un Comité de Empresa basando su resolución en que "sólo las organizaciones sindicales, titulares del derecho reconocido en el artículo 28.1 de la CE, pueden tener interés legítimo" en la defensa, ante este Tribunal, de la eficacia de los Convenios como contenido indirecto de la libertad sindical. Esta es la ratio decidendi de la Sentencia de la que discrepo (...) A continuación resumo mi tesis disidente.

2. El Comité de Empresa, actor en este proceso de amparo constitucional, tiene asignada, entre otras competencias propias, la de "ejercer una labor: a) De vigilancia en el cumplimiento de las normas vigentes en materia laboral, de Seguridad Social y empleo, así como el resto de los pactos, condiciones y usos de empresa en vigor, formulando, en su caso, las acciones legales oportunas ante el empresario y los organismos o Tribunales competentes" (artículo 64.1.8 del Estatuto de los Trabajadores). Pero al Comité de Empresa le niega la legitimatio ad causam la Sentencia de la mayoría. Nos adentramos así en ese "tormentoso capítulo de la ciencia jurídica" que es el saber de la legitimación, al decir de algunos y buenos procesalistas; legitimatio ad causam, distinta de la legitimatio ad processum, contraposición actualizada de un distingo de la vieja lógica jurídica, cuyos orígenes se pierden en la historia del derecho.

A diferencia de lo que ocurre cuando se exige la titularidad de un derecho subjetivo para la legitimación, en los procesos en que basta (como sucede en el proceso de amparo) que el recurrente tenga interés legítimo en la preservación del derecho o la libertad, este interés legítimo se configura con la garantía de una utilidad instrumental, como lo es el comportamiento del empleador según las cláusulas del Convenio colectivo y con estricto cumplimiento de ellas.

5. Resumiendo lo expuesto, si el derecho a la negociación colectiva se integra en el derecho de libertad sindical, como componente esencial del mismo, y al Comité de Empresa corresponde legalmente la vigilancia del cumplimiento del Convenio colectivo, siendo éste una garantía instrumental para los trabajadores a los que el Comité representa, la legimatio ad causam no puede ser negada al Comité, poseedor indiscutible de un interés legítimo en la preservación de la libertad sindical cuando ésta resulta violada en uno de los derechos que la forman (el de negociación colectiva, en el presente caso).

6. Admitida la legitimación del recurrente, por las razones expresadas, mi opinión es que debió otorgarse el amparo, [debido a que se presentó] una utilización masiva de la autonomía individual, para jugar sistemáticamente en detrimento y marginación de la autonomía colectiva, o vo- 
luntad general de los trabajadores, [lo que] es dudosamente compatible con las bases constitucionales de nuestro sistema de relaciones laborales. ${ }^{57}$

Como puede advertirse, el argumento elaborado por el magistrado Jiménez de Parga y Cabrera, consiste en afirmar que sí existe un vínculo o conexión entre la organización que acciona y la pretensión ejercitada, ya que si bien es cierto que la defensa del derecho de libertad sindical le corresponde constitucionalmente a las organizaciones sindicales, no menos cierto es que entre tal derecho y el derecho a la negociación colectiva existe una relación de causalidad o "utilidad instrumental”, ya que vulnerado éste se pone en juego aquél, o si se prefiere, respetando el derecho a la negociación colectiva se respeta el derecho de libertad sindical, razón por la cual si los Comités de Empresa tiene entre sus funciones vigilar el cumplimiento de las normas vigentes en materia laboral, así como el resto de los pactos, condiciones y usos de empresa en vigor (negociación colectiva), formulando, en su caso, las acciones legales oportunas ante el empresario y los organismos o tribunales competentes, no debía ser negada la legitimación al Comité de Empresa en el presente caso debido a que ello posibilitaba la defensa del derecho a la libertad sindical, sobre todo si existió - tal y como lo refiere el magistrado disidente - una utilización masiva de la autonomía individual, para jugar sistemáticamente en detrimento y marginación de la autonomía colectiva, o voluntad general de los trabajadores.

\section{El interés legítimo y la Corte Constitucional colombiana}

A diferencia del marco jurídico español, la Constitución colombiana de 1991 no establece disposición alguna que reconozca expresamente la procedencia del interés legítimo en la acción de tutela (nombre que recibe la acción de amparo en el derecho colombiano), siendo el artículo 86 de aquella Constitución el que establezca que:

Artículo 86. Toda persona tendrá acción de tutela para reclamar ante los jueces, en todo momento y lugar, mediante un procedimiento preferente y sumario, por sí misma o por quien actúe a su nombre, la protección

57 Voto particular que formula el magistrado Manuel Jiménez de Parga y Cabrera a la STC 74/1996. 
inmediata de sus derechos constitucionales fundamentales, cuando quiera que éstos resulten vulnerados o amenazados por la acción o la omisión de cualquier autoridad pública.

La protección consistirá en una orden para que aquel respecto de quien se solicita la tutela, actúe o se abstenga de hacerlo. El fallo, que será de inmediato cumplimiento, podrá impugnarse ante el juez competente $\mathrm{y}$, en todo caso, éste lo remitirá a la Corte Constitucional para su eventual revisión.

Esta acción solo procederá cuando el afectado no disponga de otro medio de defensa judicial, salvo que aquella se utilice como mecanismo transitorio para evitar un perjuicio irremediable.

En ningún caso podrán transcurrir más de diez días entre la solicitud de tutela y su resolución.

La ley establecerá los casos en los que la acción de tutela procede contra particulares encargados de la prestación de un servicio público o cuya conducta afecte grave y directamente el interés colectivo, o respecto de quienes el solicitante se halle en estado de subordinación o indefensión.

Luego, es la norma reglamentaria de tal precepto constitucional (decreto 2591 de 1991) la que pormenoriza la forma en que puede actualizarse la legitimación en la acción de tutela, señalando que:

Artículo 10. Legitimidad e Interés. La acción de tutela podrá ser ejercida, en todo momento y lugar, por cualquiera persona vulnerada o amenazada en uno de sus derechos fundamentales, quien actuará por sí misma o a través de representante. Los poderes se presumirán auténticos.

También se pueden agenciar derechos ajenos cuando el titular de los mismos no esté en condiciones de promover su propia defensa. Cuando tal circunstancia ocurra, deberá manifestarse en la solicitud.

También podrá ejercerla el Defensor del Pueblo y los personeros municipales.

Atendiendo a tal marco jurídico, la Corte Constitucional colombiana ha construido una teoría del interés legítimo a partir de lo que ha denominado "agencia oficiosa de tutela", según la cual:

...[s]e puede invocar el amparo de los derechos fundamentales, amenazados o vulnerados, personalmente o a través de representante, porque (...) el legislador consideró que para estos eventos es más importante el fondo que la forma y que más importante para el estado social de derecho 
y para la persona que la protección real, eficiente y oportuna de sus derechos fundamentales. Cuando se prevé la oportunidad de agenciamiento de derechos ajenos para el ejercicio de esta acción, se reafirma la voluntad de la ley de hacer prevalecer el respecto esencialísimo de los derechos fundamentales por encima de cualquier consideración formal. ${ }^{58}$

Es esta doctrina la que, de una u otra forma, le ha dado justificación al título de la presente investigación: el proceso debe estar al servicio de los derechos, no al revés.

Así, y en principio, conforme a esta teoría, la "agencia oficiosa de tutela" sólo procede cuando concurren dos condiciones: (i) que el titular de los derechos no esté en condiciones de defenderlos y, (ii) que en la tutela se manifieste esa circunstancia. Es decir, nótese como tiene semejanzas importantes con la "gestión de negocios" que opera en materia civil como fuente de las obligaciones, por lo que parecería no tener importancia para efectos del interés legítimo. De hecho, la mayoría de los casos en que se ha reconocido la "agencia oficiosa de tutela" se han presentado acciones de tutela por parte de, por ejemplo, la abuela en representación de su nieta, el esposo en nombre de su cónyuge, el hijo en representación de su padre; casos en los que siempre se pone de manifiesto en el escrito la razón por la cual el titular de los derechos no acude directamente, lo que, por lo general, obedece a que se trata de enfermos, limitados psíquicos o cuando el titular de los derechos se encuentra en situación de indefensión.

Sin embargo, lo anterior se ha matizado con base en la doctrina jurisprudencial de la "agencia oficiosa de tutela", debido a que la Corte Constitucional colombiana le ha dado entrada a casos sobre los que, por razones de espacio, sólo referiremos brevemente en la materia objeto del presente análisis:

\section{A. Pueblo Embera-Katio vs. Gobierno Nacional.} Sentencia T-652/98 (10 de noviembre de 1998)

En este caso, la Corte Constitucional se reconoció el interés legítimo (o agencia oficiosa de tutela) a una organización creada para la

58 T-603/92, Sala de Revisión de Tutelas de la Corte Constitucional. 11 de diciembre de 1992, ministro ponente, doctor Simón Rodríguez Rodríguez. 
defensa de derechos indígenas para reclamar la protección judicial de los derechos fundamentales de los integrantes del pueblo Embera-Katio del Alto Sinú, bajo el siguiente argumento:

En ocasión anterior, esta Corte consideró procedente la agencia oficiosa por parte de organizaciones creadas para la defensa de los derechos de los pueblos indígenas; en esta oportunidad, a más de dos de esas organizaciones, la Defensoría del Pueblo coadyuva la solicitud de amparo presentada por los representantes y miembros del pueblo Embera-Katío del Alto Sinú, por lo que con mayor razón debe reconocerse la legitimidad de los actores para reclamar la protección judicial de sus derechos y los del conglomerado al que pertenecen.

Vale señalar que el sector de los embera que respalda al cabildo de Iwagadó y a la facción encabezada por Rogelio Domicó Amarís (expediente T-168.594), planteó al juez de tutela asuntos iguales o complementarios a los que expuso el sector liderado por Alirio Pedro Domicó (expediente T-182.245); esta coincidencia de preocupaciones e intereses, refuerza la afirmación de que todos ellos constituyen un solo pueblo, y son capaces de acudir en defensa de los derechos fundamentales de la comunidad que conforman, más allá de las eventuales diferencias internas. ${ }^{59}$

\section{B. Corporación Hospitalaria Juan Ciudad vs. Ana Susana Barragán Ortiz y otros. Sentencia T-595/09 (28 de agosto de 2009)}

Este es otro de los casos en que paradójicamente una corporación solicita el amparo para defender derechos de una persona que, estando en estado vegetativo, no puede obviamente solicitar la tutela, lo cual ocurre aún en contra de la posición de los familiares de ésta. En este precedente, la Corte Constitucional reconoció el interés legítimo (o agencia oficiosa de tutela) de un Hospital para reclamar la tutela de los derechos a la vida en condiciones dignas, a la salud y la seguridad social de uno de sus pacientes en estado vegetativo (Víctor M. Barragán), quien a juicio del Hospital requería ser trasladado a otra institución médica. Lo anterior fue razonado por la Corte de la siguiente manera:

59 T-652/98, Sala Cuarta de Revisión de Tutelas de la Corte Constitucional, 10 de noviembre de

${ }^{1998,}$ ministro ponente: doctor Carlos Gaviria Díaz, consideración jurídica 2. 
Ha dicho la Corte que la denominada agencia oficiosa en materia de tutela debe reunir dos aspectos mínimos de procedibilidad que son: (i) la manifestación de estar actuando como agente oficioso a nombre de quien no está en condiciones de promover su defensa y (ii) que el titular del derecho no esté en condiciones de promover su propia defensa, condición que, como es lógico, no basta afirmar sino que es menester demostrar.

Frente al primer requisito, la Corte ha sostenido que por el carácter informal de la acción de tutela, la consagración de fórmulas sacramentales está proscrita ya que basta con que se infiera del contenido de la tutela que se obra en calidad de agente para que se entienda surtido dicho requisito.

En relación con el segundo aspecto, la Corte ha precisado que la prueba de la incapacidad del titular del derecho debe existir y tener siquiera carácter sumario. La incapacidad a la que se hace referencia cuando se habla de agencia oficiosa, atenúa la concepción tradicional de la misma (referida a minoría de edad o alienación mental) y se extiende a la incapacidad física del legítimo titular del derecho para iniciar por sí mismo la demanda.

3.2 La presente acción fue ejercida por la Corporación Hospitalaria Juan Ciudad- Hospital Universitario Mayor, como agente oficioso del señor Víctor Barragán, a través de un gestor jurídico cuyo poder para actuar consta en el expediente.

De otra parte, está ampliamente probado que el accionante se encuentra en estado neurológico vegetativo, hospitalizado y dependiente de medios artificiales para vivir, razones suficientes para que se encuentre legitimado por activa el hospital accionante para interponer la presente demanda de tutela.

Respecto de los familiares del paciente la legitimación por pasiva también se configura en la medida que se trata de personas naturales que está enfocada para tutelar a quien se encuentra en situación de subordinación o indefensión (...) Que para el caso es el señor Barragán está demostrado que se encuentra en estado de indefensión absoluta, toda vez que no tiene la capacidad ni física ni absoluta para decidir sobre su traslado. ${ }^{60}$

60 T-595/09, Sala Novena de Revisión de la Corte Constitucional, 28 de agosto de 2009, ministro ponente: doctor Jorge Iván Palacio Palacio, consideración jurídica 3. 


\section{Comité Comunitario para el Desarrollo Integral del Adulto Mayor vs. Alcalde de Montería. Sentencia T-961/09 (18 de diciembre de 2009)}

En este caso, la Corte Constitucional colombiana reconoció el interés legítimo (o agencia oficiosa de tutela) de una organización creada para la defensa de los derechos de los adultos mayores para reclamar determinados actos del Alcalde de Montería por considerarlos violatorios de los derechos a la vida, a la salud, al trabajo, a la educación y a la protección reforzada de personas de la tercera edad. Lo ejemplificativo de este precedente se encuentra en que tal reconocimiento lo hizo la Corte, incluso flexibilizando su propia doctrina, según la cual, la agencia oficiosa en materia de tutela debe reunir dos aspectos mínimos de procedencia: (i) la manifestación de estar actuando como agente oficioso a nombre de quien no está en condiciones de promover su defensa, y (ii) que el titular del derecho no esté en condiciones de promover su propia defensa.

Lo anterior fue realizado por la Corte - precisamente- bajo la premisa de que el interés legítimo sirve para garantizar tres principios constitucionales, a saber: (i) la primacía del derecho sustantivo sobre el derecho adjetivo; (ii) la eficacia de los derechos fundamentales, y (iii) la informalidad de la acción de tutela o juicio de amparo. Así, y en pocas palabras, tales principios deben ser los determinantes para la construcción de cualquier doctrina que sobre interés legítimo quiera diseñarse. La Corte lo razonó de la siguiente manera:

3.1. Particular relevancia tiene, en el presente caso, la agencia oficiosa. Según el artículo 10 del Decreto 2591 de 1991, pueden agenciarse derechos ajenos „cuando el titular de los mismos no esté en condiciones de promover su propia defensa. Cuando tal circunstancia ocurra, deberá manifestarse en la solicitud". Por lo tanto, para que se configure la agencia oficiosa, deben concurrir dos condiciones: (i) que el titular de los derechos no esté en condiciones de defenderlos y, (ii) que en la tutela se manifieste esa circunstancia.

Pues bien, en este caso no está dada ninguna de esas condiciones de un modo evidente. En efecto, ni está probado plenamente que los titulares cuyos derechos se invocan estén en incapacidad de defenderlos por sí mismos, ni tampoco hay evidencias de ello en la acción de tutela. Sin embargo, es necesario resaltar que los requerimientos de la agencia oficiosa 
están enmarcados en un contexto constitucional más amplio, que garantiza, entre otros principios, la primacía del derecho sustancial sobre el adjetivo (artículo 228, de la CP), la eficacia de los derechos fundamentales (artículo 2o., de la CP) y la informalidad de la acción de tutela (artículo 14, Documento 2591 de 1991). En ese contexto, el juez constitucional tiene el deber de concederle primacía al derecho sustancial involucrado en la controversia, lo que implica que le está prohibido detenerse en las formas empleadas por los peticionarios para hacer determinada manifestación, exigida por la ley. En otras palabras, para configurarse la agencia oficiosa no se requiere que de manera explícita el afectado señale su imposibilidad para interponer directamente la acción constitucional. De hecho, esta condición puede estar expresada de manera tácita en la acción, y será función del operador constitucional percatarse de dicha situación. Esto es así debido a que el juez de tutela cumple, ante todo, un rol protagónico en la protección de derechos fundamentales, que no sólo lo faculta para solicitar correcciones a la solicitud de amparo, sino también para decretar pruebas oficiosamente. Si se abstiene de desplegar los poderes que la Constitución y la ley le confieren, no puede permitir que ello repercuta desfavorablemente en quien reclama la protección de sus derechos fundamentales.

Así las cosas, en este caso aún cuando no se hace explícito el motivo por el cual las personas cuyos derechos pretenden tutelarse no pueden interponer, por sí mismas, la acción de tutela, se trata de adultos mayores, que superan la tercera edad. Esa clase de personas merecen de parte del Estado una mayor consideración, justamente porque están en condiciones de debilidad manifiesta, que si bien no les impiden ejercer autónomamente sus derechos, sí les dificultan de un modo sensible la agencia de sus propios intereses. De hecho, la jurisprudencia de la Corte ha admitido la agencia oficiosa de las personas que se encuentren en condiciones de debilidad manifiesta en casos, por ejemplo, de menores de edad; personas de la tercera edad; las personas amenazadas en su vida o integridad personal; los disminuidos físicos, psíquicos o sensoriales; las personas pertenecientes a determinadas minorías étnicas y culturales; las personas que se encuentren privadas de la libertad, entre otros. Por lo tanto, pese a que no esté directa, abierta y expresamente señalado así en la tutela, hay buenas razones para considerar que los titulares de los derechos agenciados no están en una situación óptima que les permita ejercer, en condiciones ideales, sus derechos fundamentales por sí mismos. ${ }^{61}$

61 T-961/09, Sala Segunda de Revisión de la Corte Constitucional, 18 de diciembre de 2009, ministra ponente: doctora María Victoria Calle Correa, consideración jurídica 3. 
D. Corporación Colectivo de Abogados José Alvear Restrepo vs. Presidente de la República. Sentencia T-1062/05 (20 de octubre de 2005)

En este otro asunto, la Corte Constitucional colombiana reconoció el interés legítimo de una Corporación Colectiva de Abogados dedicada a la defensa de los derechos humanos para reclamar la violación a los derechos fundamentales de sus miembros por las declaraciones del Presidente Uribe en las que afirmó que: “...no se puede utilizar el tema de los derechos humanos como excusa para dar cobertura a los terroristas". Lo que después sería acompañado de la siguiente expresión: “...si el colectivo de Abogados quiere defender terroristas, que lo haga según el derecho, pero que no se escude en organizaciones de derechos humanos".

La Corte es esa ocasión razonó de la siguiente manera:

En relación con el primer interrogante que suscita la presente demandada, y que fue puesto de manifiesto por la abogada del Presidente de la República, esta Sala considera que la Corporación Colectivo de Abogados se encuentra legitimada para incoar la acción de tutela de la referencia, toda vez que los miembros de dicha organización cuyos derechos fundamentales se dicen vulnerados, tienen en la Corporación a un representante legítimo de sus intereses.

En esa medida, atendiendo a lo dicho por esta Sala de Revisión en Sentencia T-1191 de 2004, la misma reconoce que las asociaciones encargadas de la defensa de los derechos humanos, en cuanto que representan legítimamente los intereses de sus asociados y están encargadas, en su calidad de garantes, de la función de adoptar las medidas necesarias para permitir el desempeño efectivo de actividades relacionadas con la defensa de los derechos humanos, las cuales, por disposición de normas internacionales y reconocimiento jurisprudencial, merecen una protección reforzada de las autoridades del Estado, están legitimadas para interponer acciones de tutela que tiendan a la protección de los derechos fundamentales de sus activistas. 


\section{E. Jobar Otero Cruz vs. Fondo Nacional de Vivienda.} Sentencia T-177/10 (12 de marzo de 2010)

Este asunto resulta interesante debido a que la Corte Constitucional colombiana reconoció el interés legítimo (o agencia oficiosa de tutela) de un hijo para reclamar el acto por el cual se negó a su madre un subsidio del Fondo Nacional de Vivienda al que decían tener derecho por su carácter de desplazados. En esta sentencia, la Corte apeló expresamente a la teoría del interés legítimo para justificar la admisibilidad de la demanda, ya que atendió a la especial posición jurídica que guarda el hijo como miembro del núcleo familiar. La Corte lo razonó así:

Por otro lado, debe considerarse que si bien todas las previsiones normativas respecto de la protección, ayuda humanitaria y programas de restablecimiento económico de la población desplazada están dirigidas a favorecer a cada individuo que se encuentre en situación de desplazamiento, el hecho de que usualmente las personas se ven obligadas a migrar con toda su familia y que la protección de algunos derechos individuales redundan en el bienestar de toda ella, hace que muchos de los componentes de la asistencia que brinda el Estado deban ser solicitados por el jefe del hogar, pero que sean entregados con destino a los núcleos familiares. Por lo tanto, en los componentes de ayuda de los que pueda predicarse su entrega colectiva, la adjudicación o negación de los mismos afecta individualmente a cada miembro del grupo familiar, así este haya sido solicitado por quien está registrado como jefe del hogar.

2.4 En el caso concreto, se encuentra que si bien la señora Manuela Cruz Trochez fue quien presentó los documentos para acceder a la convocatoria de subsidios de vivienda para desplazados del año 2007, obra en el expediente prueba de que el accionante, Jobar Otero Cruz, forma parte del núcleo familiar de la señora Cruz Trochez. Así las cosas, la negación del subsidio de vivienda puede afectar de manera directa sus derechos fundamentales, máxime teniendo en cuenta que comparte con su núcleo familiar la condición de desplazados y no posee una solución de vivienda diferente. Esto significa que tiene un interés legítimo y actual para promover la tutela.

Ahora bien, quizá uno de los casos en los que la Corte Constitucional colombiana ha interpretado con mayor flexibilidad la institución de "agencia oficiosa de tutela", fue el siguiente: 
F. Ana Paulina Guevara Morantes en representación del menor Cristian Parra Garzón vs. Compensar E.P.S. (régimen contributivo de salud). Sentencia T-1199/05 (23 de noviembre de 2005)

Como lo he mencionado, este es uno de los casos en que la Corte ha flexibilizado en mayor medida su doctrina de la "agencia oficiosa de tutela", ya que la Corte analizó si una abuela tenía o no legitimación para plantear el amparo en favor de su nieto, concluyendo que sí, debido a que existe un interés legítimo de toda persona para proteger los derechos fundamentales de los menores. La Corte lo razonó así:

En el supuesto bajo examen se observa que la señora Ana Paulina Guevara Morantes ejerce la representación judicial de su nieto y dada esta circunstancia resulta preciso recordar que en ningún caso podría argüirse o plantearse la falta de legitimidad para actuar en procura de la protección de los derechos fundamentales de éste.

En efecto, la jurisprudencia de esta Corporación, a partir de la interpretación del artículo 44 de la Constitución Política y en particular de lo expresado en el sentido que [T] oda persona puede exigir de la autoridad competente su cumplimiento y la sanción de los infractores", ha tenido oportunidad de advertir que la protección judicial de los derechos fundamentales de los niños a través de la acción de tutela puede darse por la iniciativa de cualquier persona -natural o jurídica.

Sobre este particular, esta Sala de revisión expresó: "Cualquier persona está legitimada para interponer acción de tutela en nombre de un menor, siempre y cuando en el escrito o petición verbal conste la inminencia de la violación a los derechos fundamentales del niño, o la ausencia de representante legal (énfasis nuestro).

En este caso concreto la ausencia de los representantes legales del menor se explica en que el padre de éste no se ha hecho responsable de ninguna de sus necesidades — lo cual no la justifica - y la madre es una adolescente que se encontraba en un precario estado de salud y que a su vez depende por entero de su madre, circunstancias que con suficiencia justifican el proceder de la abuela, al tiempo que descartan por completo que estemos frente a una intervención ilegítima o inconsulta, única circunstancia que permitiría llegar a una conclusión contraria sobre este particular. 
Tal y como se relata, esta resolución encuentra su justificación en el hecho de que la Constitución colombiana, en su artículo 44 señala que: "Cualquier persona puede exigir de la autoridad competente [el] cumplimiento [de los derechos de los niños] y la sanción de los infractores. Los derechos de los niños prevalecen sobre los derechos de los demás", lo cual, dicho sea de paso, toma especial relevancia para el caso del sistema constitucional mexicano, sobre todo si existe en el artículo 4o. de la Constitución mexicana, un principio que señala lo siguiente: "El Estado otorgará facilidades a los particulares para que coadyuven al cumplimiento de los derechos de la niñez".

En este sentido, bien cabe hacerlos la siguiente interrogante: ¿podría interpretarse que esas „facilidades" a las que se refiere el artículo 40. constitucional para „coadyuvar" en el cumplimiento de los derechos de la niñez, alcancen para llegar a una conclusión como a la que arribó la Corte Constitucional colombiana? Interesante pregunta que deberán contestar los jueces constitucionales mexicanos al momento de que comiencen a diseñar una doctrina del interés legítimo para nuestro país.

\section{La conclusión}

"El interés legítimo (...) es un concepto más amplio que el de interés directo (...) y, por tanto, de mayor alcance que el de derecho subjetivo afectado o conculcado por el acto o disposición objeto del recurso...".

Tribunal Constitucional de España

Como ya lo he manifestado líneas arriba, considero que el tránsito del interés jurídico al interés legítimo realizado desde, y por la Constitución, no hace sino impregnar a la misma de un "neoconstitucionalismo procesal", lo cual implica un mensaje claro y contundente a los poderes constituidos, especialmente a los órganos jurisdiccionales: las normas procesales debe interpretarse teniendo siempre presente el fin perseguido por el legislador al establecerlas, evitando cualquier exceso formalista que convierta a tales normas en meros obstáculos procesales que impidan el acceso a la justicia. 
De esta manera, la sola mención de los precedentes aquí analizados, así como su configuración, argumentación y contenido nos dejan ver que hay mucho por hacer en México en torno a la concreción de tal decisión axiológica fundamental tomada por el Poder Constituyente constituido, y que se deriva no sólo de la aprobación de la reforma constitucional en materia de amparo, sino sobre todo, de la relación que ésta última tiene con la reforma constitucional en materia de derechos humanos, así como con la reforma que constitucionalizó las acciones colectivas: el neoconstitucionalismo procesal implica que el proceso debe estar al servicio de los derechos.

Lo demás, es lo de menos. 